\title{
IF HE HOLLERS LET HIM GO: REGULATING RACIST SPEECH ON CAMPUS
}

\author{
Charles R. LAWrence III*
}

\section{NEWSREEL ${ }^{1}$}

Racist incidents at the University of Michigan, University of Massachusetts-Amherst, University of Wisconsin, University of New Mexico, Columbia University, Wellesley College, Duke University, and University of California-Los Angeles. ${ }^{2}$

The campus ought to be the last place to legislate tampering with the edges of first amendment protections.

University of Michigan:

"Greek Rites of Exclusion": Racist leaflets in dornus, white students paint theinselves black and place rings in their noses at "jungle parties."3

Silencing a few creeps is no victory if the price is an abrogation of free speech. Remember censorship is an ugly word too.

Copyright $\odot$ Charles R. Lawrence III 1990.

- Professor of Law, Stanford Law School, Stanford University. B.A., 1965, Haverford College; J.D., 1969, Yale Law School. I wish to acknowledge the American Civil Liberties Union Biennial Conference, Stanford Law School, and the Duke University School of Law where tentative versions of this Article along with Professor Strossen's Article, infra, were presented. I am indebted to Stephen Arons, Thomas Grey, and Sylvia Law for their helpful comments on earlier drafts, to David Drummond, Marti Paschal, and Mark Niles for their research assistance, to Richard Delgado and Mari Matsuda for their trailblazing work on the subject of racist speech, and to countless others who have challenged and supported me in my efforts to understand this issue. The title of this Article is inspired by the work by CHESTER H1MES, IF He Hollers LET H1M Go (1945).

An earlier version of this Article, along with an earlier version of Professor Strossen's Article, Regulating Racist Speech on Campus: A Modest Proposal?, 1990 DukE L.J. 484, were presented as papers for a plenary session of the 1989 Biennial Conference of the American Civil Liberties Union. Papers presented at this session served as a basis of discussion by delegates in small working groups who then proposed policy resolutions for adoption by the convention. Following a spirited debate, a resolution supporting narrowly framed restrictions of racist speech on campuses was defeated by the convention.

1. The events that appear in this newsreel are gathered from newspaper and magazine reports of racist incidents on campuses. Each of them is followed by a statement, appearing in italics, criticizing proposals to regulate racism on campus. The latter have been garnered from conversations, debates, and panel discussions at which I have been present. Some I managed to record verbatim and are exact quotes; others paraphrase the sentiment expressed. I have heard some version of each of these arguments many times over.

2. White, The New Racists, Ms. MAG., Oct. 1987, at 68.

3. Lord, Frats and Sororities: The Greek Rites of Exclusion, NATion, July 4, 1987, at 10. 
Northwest Missouri State University:

White Supremacists distribute flyers stating, "The Knights of the $\mathrm{Ku}$ Klux Klan are Watching You."4

Kansas Umiversity:

KKK members speak. ${ }^{5}$

Temple Umiversity:

White Student Union formed. ${ }^{6}$

Stanford University:

Aryan Resistance hiterature distributed.7

Stockton State College (New Jersey):

Invisible Empire literature distributed. ${ }^{8}$

Memphis State University:

Bomb Threats at Jewish Student Union. ${ }^{9}$

Arizona State University:

Shot fired at Hillel Foundation building. ${ }^{10}$

The harm that censors allege will result unless speech is forbidden rarely occurs.

Dartmouth College:

Black professor called "a cross between a welfare queen and a bathroom attendant" and the Dartmouth Review purported to quote a black student, "Dese boys be sayin' that we be comin' here to Dartmut an' not takin' the classics. ..."11

Yes, speech is sometimes painful. Sometimes it is abusive. That is one of the prices of a free society.

Purdue University:

Counselor finds "Death Nigger" scratched on her door. ${ }^{12}$

More speech, not less, is the proper cure for offensive speech.
4. Klanwatch INTElligence Report No. 42, Feb. 1988.
5. Id.
6. Id.
7. Id.
8. Id.
9. Id.
10. Id.
11. Wiener, Racial Hatred on Campus, NATION, Feb. 27, 1989, at 260.
12. Id. 
Smith College:

African student finds message slipped under her door that reads, "African Nigger do you want some bananas? Go back to the Jungle."13

Speech cannot be banned simply because it is offensive.

University of Michigan:

Campus radio station broadcasts a call from a student who "joked": "Who are the most famous black women in history? Aunt Jemima and Mother Fucker."14

Those who don't like what they are hearing or seeing should try to change the atmosphere through education. That is what they will have to do in the real world after they graduate.

University of Michigan:

A student walks into class and sees this written on the blackboard: "A mind is a terrible thing to waste-especially on a nigger."1s

People of color, women, and gays and lesbians owe their vibrant political movements in large measure to their freedom to communicate. If speech can be banned because it offends someone, how long will it be before the messages of these groups are themselves found offensive?

Stanford University:

"President Donald Kennedy refused yesterday to consider amnesty for students who took over his office last week. ... Kennedy insisted that the probe of violations of the Stanford behavior code go forward. The students [who were demanding more minority faculty and ethnic studies reforms] consider the prospect of disciplinary action unfair in view of Stanford's decision earlier this year not to punish two white students who defaced a poster of 19th century composer Ludwig von Beethoven to portray a stereotypical black face, then tacked it up in a predominantly black dormitory. The two incidents differ sharply, Kennedy said. The poster was admittedly racially offensive. But its defacement probably was protected by constitutional freedoms. However, the office takeover was 'clearly a violation' of Stanford's policy against campus disruption."16

Now it's the left that is trying to restrict free speech ... . [t]hough the

13. Lewis, Amid Push for Diversity, Smith Struggles with Racism, Boston Globe, May 4, 1989, $\S 1$, at 1, col. 2 .

14. Wiener, supra note 11 , at 260.

15. Hundley, Black Students Take Action, Chicago Tribune, Apr. 23, 1989, § 1, at 4, col. 1.

16. Workman, Stanford President Denies Amnesty to Students, San Francisco Chron., May 25, 1989, at A8, col. 1. 
political labels have shifted, the rationale is the same: Our adversaries are dangerous and therefore should not be allowed to speak. ${ }^{17}$

\section{INTRODUCTION}

In recent years, American campuses have seen a resurgence of racial violence and a corresponding rise in the incidence of verbal and symbolic assault and harassment to which blacks and other traditionally subjugated groups are subjected. ${ }^{18}$ There is a heated debate in the civil liberties community concerning the proper response to incidents of racist speech on campus. Strong disagreements have arisen between those individuals who believe that racist speech, such as that contained in the Newsreel that opens this Article, should be regulated by the university or some public body and those individuals who believe that racist expression should be protected from all public regulation. At the center of the controversy is a tension between the constitutional values of free speech and equality. Like the debate over affirmative action in university adinissions, this issue has divided old allies and revealed unrecoguized or unacknowledged differences in the experience, perceptions, and values of members of longstanding alliances. It also has caused considerable soulsearching by individuals with long-time commitments to both the cause of potitical expression and the cause of racial equality.

I write this Article from within the cauldron of this controversy. ${ }^{19}$ I make no pretense of dispassion or objectivity, but I do claim a deep commitment to the values that motivate both sides of the debate. ${ }^{20}$ As I struggle with the tension between these constitutional values, I particularly appreciate the experience of both belonging and not belonging that gives to African Americans and other outsider groups a sense of duality.

17. Dembart, At Stanford, Leftists Become Censors, N.Y. Times, May 5, 1989, at A35, col. 2.

18. The incidents contained in the "Newsreel" are but a small sampling of the hate speech to which minorities are subjected on a daily basis on our nation's college campuses. For a catalogue of numerous other examples of such incidents, see H. EHRLICH, CAMPUS ETHNOVIOLENCE AND THE Policy Options 41-72 (National Institute Against Prejudice \& Violence, Institute Report No. 4 1990).

19. See Dembart, supra note 17; Will, Liberal Censorship, Wash. Post, Nov. 5, 1989, at C7, col. 4; France, Hate Goes to College, A.B.A. J., July 1990, at 44-49; Blum and Lobaes, Fighting Words at the $A C L U$, CALIF. LAW., Feb. 1990, at 44.

20. I have spent the better part of my life as a dissenter. As a high school student I was threatened with suspension for my refusal to participate in a civil defense drill, and $I$ have been a conspicuous consumer of my first amendment liberties ever since. I also have experienced the injury of the historical, ubiquitous, and continuous defamation of American racism. I grew up with Little Black Sambo and Amos and Andy (for an autobiographical narrative reeounting my encounters with these American cultural artifacts, see Lawrence, The Id, the Ego and Equal Protection: Reckoning with Unconscious Racism, 39 STAN. L. REV. 317, 317-18 (1987)), and I continue to receive racist tracts in the mail and shoved under my door. 
W.E.B. Du Bois-scholar and founder of the National Association for the Advancement of Colored People-called the gift and burden inherent to the dual, conflicting heritage of all African Americans their "secondsight." 21

The "double consciousness" of groups outside the ethnic inainstream is particularly apparent in the context of this controversy. Blacks know and value the protection the first amendment affords those of us who inust rely upon our voices to petition both government and our neighbors for redress of grievances. Our pohtical tradition has looked to "the word," to the moral power of ideas, to change a system when neither the power of the vote nor that of the gun are available. This part of us has known the experience of belonging and recognizes our coinmon and inseparable interest in preserving the right of free speech for all. But we also know the experience of the outsider. The Framers excluded us froin the protection of the first amendment. ${ }^{22}$ The same Constitution that estabhished rights for others endorsed a story that proclaimed our inferiority. It is a story that remains deeply ingrained in the American psyche. ${ }^{23}$

We see a different world than that which is seen by Americans who do not share this historical experience. ${ }^{24}$ We often hear racist speech when our white neighbors are not aware of its presence. ${ }^{25}$

It is not my purpose to belittle or trivialize the importance of defending unpopular speech against the tyranny of the majority. There are very strong reasons for protecting even racist speech. Perhaps the most important reasons are that it reinforces our society's commitment to the

21. W.E.B. Du Bois, The Souls of Black Folk 16-17 (1953). According to Du Bois,

[T] he Negro is a sort of seventh son, born with a veil, and gifted with second-sight in this American world-a world which yields him no true self-consciousness, but only lets him see himself through the revelation of the other world. It is a peculiar sensation, this double consciousness, this sense of always looking at one's self through the eyes of others, of measuring one's soul by the tape of a world that looks on in amused contempt and pity. One ever feels his two-ness-an American, a Negro; two souls, two thoughts, two unrcconciled strivings; two warring ideals in one dark body, whose dogged strength alone keeps it from being torn asunder.

22. In Dred Scott v. Sanford, 60 U.S. (19 How.) 393 (1857), the Court declared that at the time of the Declaration of Independence, and when the Constitution of the United States was framed and adopted "[blacks] had no rights which the white man was bound to respect." Id. at 407. See A. L. Higginbotham, IN THE MATter of Color (1978), for an analysis of statutes and judicial decisions that denied the rights of blacks during the colonial period.

23. Lawrence, supra note 20.

24. See, e.g., Freeman, Legitimizing Racial Discrimination Through Anti-Discrimination Law: A Critical Review of Supreme Court Doctrine, 62 MINN. L. REv. 1049 (1978) (discussion of antidiscrimination laws from African-American perspective).

25. See Matsuda, Public Response to Racist Speech: Considering the Victim's Story, 87 Mich. L. REV. 2320 (1989). Matsuda points out that the "mainstream press often ignores these stories [of racist speech and violence], giving rise to the view of racist and anti-Semitic incidents as random and isolated, and the corollary that isolated incidents are inconsequential." Id. at 2331. 
value of tolerance, ${ }^{26}$ and that, by shielding racist speech from government regulation, we will be forced to combat it as a community. These reasons for protecting racist speech should not be set aside hastily, and I will not argue that we should be less vigilant in protecting the speech and associational rights of speakers with whom most of us would disagree.

But I am deeply concerned about the role that many civil libertarians have played, or the roles we have failed to play, in the continuing, real-life struggle through which we define the community in which we live. I fear that by framing the debate as we have-as one in which the liberty of free speech is in conflict with the elimination of racism-we have advanced the cause of racial oppression and have placed the bigot on the moral high ground, fanning the rising flames of racism. Above all, I am troubled that we have not listened to the real victims, that we have shown so little empathy or understanding for their injury, and that we have abandoned those individuals whose race, gender, or sexual orientation provokes others to regard them as second class citizens. These individuals' civil liberties are most directly at stake in the debate. ${ }^{27}$

I have set two goals in constructing this Article. The first goal is limited and perhaps overly modest, but it is nonetheless extremely important. I will demonstrate that much of the argument for protecting racist speech $^{28}$ is based on the distinction that many civil libertarians draw between direct, face-to-face racial insults, which they think deserve first

\section{L. BOLIINGER, THE TOLERANT SOCIETY 7-8 (1986).}

27. This paper will focus on racism. Although much of my analysis applies to violent pornography and homophobic hate speech, I will not address those problems directly. I will on occasion draw on the experience of women and gays as victims of hate speech where they operate as instructive analogues.

28. Most of these proposals are university regulations drafted in an effort to stem the tide of virulent racist verbal attacks on students of color. Institutions that have adopted policies include: University of California, Emory University, University of Texas, University of Wisconsin, University of Connecticut, University of Michigan, University of North Carolina-Chapel Hill, Tufts University, University of Pennsylvania, and Trinity College. Wilson, Colleges' Anti-Harassment Policies Bring Controversy Over Free-Speech Issues, Chron. Higher Educ., Oct. 4, 1989, at Al, col. 2. Other more far reaching proposals for regulating racist speech outside of the campus setting have appeared in the academic literature. See, e.g., Arkes, Civility and the Restriction of Speech: Rediscovering the Defamation of Groups, 1974 SUP. CT. REv. 281 (advocating group libel approach); Delgado, Words That Wound: A Tort Action for Racial Insults, Epithets, and Name-Calling, 17 HARV. C.R.-C.L. L. REV. 133 (1982) (proposing cause of action for tort of racial insult); Downs, Skokie Revisited: Hate Group Speech and the First Amendment, 60 Notre DAME L. Rev. 629 (1985) (test to invalidate racial hate speech based on assaultive intent and targeting of victims); Kretzmer, Freedom of Speech and Racism, 8 CARDOzo L. Rev. 445 (1987) (outlawing racist speech); Rabinowitz, Nazis in Skokie: Fighting Words or Heckler's Veto?, 28 DE PAUL L. Rev. 259 (1979) (use of fighting words doctrine to limit racist speech); Comment, Freedom From Fear, 15 Lincoln L. Rev. 45 (1984) (relax clear and present danger standard in cases where racial hatred is involved). Racist speech is rcgulated indirectly under the hostile work environment provisions of Title VII of the Civil Rights Aet of 1964, and fair election provisions of the National Labor Relations Act. See, e.g., Sewell Mfg. Co., 138 
amendment protection, and all other fighting words, which they concede are unprotected by the first amendment. ${ }^{29}$ I argue that the distinction is false, advances none of the purposes of the first amendment, and that it is time to put an end to the ringing rhetoric that condemns all efforts to regulate racist speech, even wnen those efforts take the form of narrowly drafted provisions aimed at racist speech that results in direct, immediate, and substantial injury.

I also urge the regulation of racial epithets and vilification that do not involve face-to-face encounters-situations in which the victim is a captive audience and the injury is experienced by all members of a racial group who are forced to hear or see these words; the insulting words, in effect, are aimed at the entire group.

My second goal is more ambitious and more indeterminate. I propose several ways in which the traditional civil liberties position on free speech does not take into account important values expressed elsewhere in the Constitution. Further, I argue that even those values the first amendment itself is intended to promote are frustrated by an interpretation that is acontextual and idealized, by presupposing a world characterized by equal opportunity and the absence of societally created and culturally ingrained racism.

This Article is divided into four parts: Part I explores whether our Constitution already commits us to some regulation of racist speech..$^{30} \mathrm{I}$ argue that it does, that this is the meaning of Brown v. Board of Education. ${ }^{31}$ For the time being, I would ask only that the reader be open to considering this interpretation of Brown. It is an idea that contains a lesson that is useful even for those who believe the censorship of any expression cannet ultimately be condoned: Brown can help us better understand the injury of racist speech, an understanding that is vital to our discussion.

I also consider the implications of the state action doctrine in understanding Brown and argue that the public/private ideology promoted by that doctrine plays a critical role in advancing racism and clouding our

N.L.R.B. 66 (1962) (setting aside a union election in which the employer used racially inflammatory campaign materials).

29. A significant number of civil libertarians do not agree with the "fighting words" doctrine and will argue for first amendment proteetion of all face-to-face insults. Nevertheless, the Court has yet to reject the reasoning in Chaplinsky v. New Hampshire, 315 U.S. 568 (1942). And there is no evidence that the continued usage of this approach has led down the slippery slope to rampant censorship.

30. See infra notes $36-81$ and accompanying text.

31. 347 U.S. 483 (1954). 
vision of the appropriate role for the community in disestablishing systematic, societal group defamation. ${ }^{32}$

Part II considers the debate over regulation of racial harassment on campus. ${ }^{33}$ I argue that carefully drafted regulations can and should be sustained without significant departures from existing first amendment doctrine. The regulation of racist fighting words should not be treated differently than the regulation of garden variety fighting words, and captive audiences deserve no less protection when they are held captive by racist speakers. I also suggest that rules requiring civility and respect in academic discourse encourage rather than discourage the fullest exchange of ideas. Regulations that require civility of discourse in certain desiguated forums are not incursions on intellectual and political debate.

Part III explores the nature of the injury inflicted by racist hate speech and examines the unstated assumptions that lie at the core of first amendment theory. ${ }^{34}$ In this Part, I urge reconsideration of the history of racism im America, the ubiquity and continued vitality of culturally engendered conscious and unconscious beliefs about the inferiority of non-whites and the effect of inequities of power on the marketplace of ideas.

In Part IV, I argue that civil libertarians must examine not just the substance of our position on racist speech but also the ways in which we enter the debate. ${ }^{35}$ The way the debate has been framed makes heroes out of bigots and fans the flames of racial violence. I also consider the reasons for some civil libertarians' resistance to even minimal and narrowly drafted regulations of racist harassment.

\section{BRown v. BoARD of EDUCATION: A CASE About Regulating RACIST SPEECH}

The landmark case of Brown v. Board of Education is not a case we norinally think of as a case about speech. As read most narrowly, the case is about the rights of black children to equal educational opportumity. But Brown can also be read more broadly to articulate a principle central to any substantive understanding of the equal protection clause, the foundation on which all anti-discrimination law rests. This is the principle of equal citizenship. Under that principle "every individual is presumptively entitled to be treated by the organized society as a

32. See infra notes $60-81$ and accompanying text.

33. See infra notes $82-103$ and accompanying text.

34. See infra notes $104-58$ and accompanying text.

35. See infra notes $159-69$ and accompanying text. 
respected, responsible, and participating member." 36 Furthermore, it requires the affirmative disestablishment of societal practices that treat people as members of an inferior or dependent caste, as unworthy to participate in the larger community. The holding in Brown-that racially segregated schools violate the equal protection clause-reflects the fact that segregation amounts to a demeaning, caste-creating practice. ${ }^{37}$

The key to this understanding of Brown is that the practice of segregation, the practice the Court held inherently unconstitutional, was speech. Brown held that segregation is unconstitutional not simply because the physical separation of black and white children is bad ${ }^{38}$ or because resources were distributed unequally among black and white schools. ${ }^{39}$ Brown held that segregated schools were unconstitutional primarily because of the message segregation conveys-the message that black children are an untouchable caste, unfit to be educated with white children. ${ }^{40}$ Segregation serves its purpose by conveying an idea. It stamps a badge of inferiority upon blacks, and this badge communicates

36. Karst, Citizenship, Race and Marginality, 30 WM. \& MARY L. REV. 1, 1 (1988).

37. The prevention of stigma was at the core of the Supreme Court's unanimous decision in Brown v. Board of Education, 347 U.S. 483 (1954), that segregated public schools are inherently unequal. Observing that the segregation of black pupils "generates a feeling of inferiority as to their status in the community," $i d$. at 494, Chief Justice Warren recognized what a majority of the Court had ignored almost sixty years earlier in Plessy v. Ferguson, 163 U.S. 537 (1896): The social mcaning of racial segregation in the United States is the designation of a superior and an inferior caste, and segregation proceeds "on the ground that colored citizens are ... inferior and degraded." Id. at 560 (Harlan, J., dissenting); see also Black, The Lawfulness of the Segregation Decisions, 69 YALE L.J. 421, 427 (1960); Brest, The Supreme Court, 1975 Term-Forward: In Defense of the Antidiscrimination Principle, 90 HARV. L. REv. 1, 8-12 (1976); Cahn, Jurisprudence, 30 N.Y.U. L. REv. $150,158-59$ (1955); Lawrence, supra note 20 , at $349-55$. Note that while formal, legally sanctioned segregation was the chief form of stigmatization prior to Brown and the Civil Rights Act of 1964, 28 U.S.C. $\S \S 1443,1447$ (1988), 42 U.S.C. $\S \S 1971,1975 \mathrm{a}-1975$ d, $2000 \mathrm{a}$ to $2000 \mathrm{~h}-6$ (1988), the system has yet to be dismantled, and other stigmatizing meehanisms-including the exclusion of blacks from private clubs, privately enforced housing diserimination, and deprecating portrayals of blacks in the media-have reinforced its effects. See Lawrence, Negroes in Contemporary Society, in MaN, Culture AND SocieTY 52, 59 (C. Lawrence ed. 1962). For a discussion of segregation as an institutionalized, self-perpetuating mechanism of stigmatization, see Lawrence, supra note 20.

38. Brown is not a case about the right of black children to associate with white children. See Black, supra note 37, at 421, 427-29, responding to the argnment put forward in Weschler, Toward Neutral Principles of Constitutional Law, 73 HARV. L. Rev. 1, 31-34 (1959), that Brown was wrongly decided because it did not consider the non-associational rights of white students.

39. Although separate but equal was never a reality in the segregated sehool systems of America, the Court assumed an equality of resources in Brown and its companion cases in order to consider plaintiff's argument directly challenging the constitutionality of the separate but equal doctrine of Plessy, see Brown, 347 U.S. at 492.

40. For discussion of the "cultural meaning" of segregation, see Black, supra note 37; Lawrence, Segregation "Misunderstood": The Milliken Decision Revisited?, 12 U.S.F. L. REV. 15 (1977); Wasserstrom, Racism, Sexism and Preferential Treatment: An Approach to the Topics, 24 UCLA L. REV. 581 (1977). 
a message to others in the community, as well as to blacks wearing the badge, that is injurious to blacks. Therefore, Brown may be read as regulating the content of racist speech. As a regulation of racist speech, the decision is an exception to the usual rule that regulation of speech content is presumed unconstitutional. ${ }^{41}$

\section{A. The Conduct/Speech Distinction}

Some civil libertarians argue that my analysis of Brown conflates speech and conduct. They maintain that the segregation outlawed in Brown was discriminatory conduct, not speech, and the defamatory message conveyed by segregation simply was an incidental by-product of that conduct. This position is often stated as follows: "Of course segregation conveys a message but this could be said of almost all conduct. To take an extreme example, a murderer conveys a message of hatred for his victim. [But], we would not argue that we can't punish the murderthe primary conduct-merely because of this message which is its secondary byproduct." 42 This objection to my reading of Brown misperceives the central point of the argument. I have not ignored the distinction between the speech and conduct elements of segregation by mistake. Rather, my analysis turns on that distinction. It asks the question whether there is a purpose for outlawing segregation that is unrelated to its message, ${ }^{43}$ and it concludes the answer is "no."

41. It is important to note that Brown is a case about the State engaging in racist speech and that the first amendment protects individuals not the state. Stated another way, Brown invokes the fourteenth amendment which prohibits states, and not individuals, from denying equal protection of the laws. Although this is true, I believe that reliance on the state action doctrine in this context avoids the real issue. It also should be noted that anti-discrimination laws prohibiting segregation by private parties such as Title II of the Civil Rights Act of 1964, 42 U.S.C. $\S \S 2000$ a to 2000a-6 (1988) (public accommodations), Title VI, 42 U.S.C. $\$ \S 2000 \mathrm{~d}-1$ to $2000 \mathrm{~d}-7$ (1988) (federally assisted programs), Title VII, 42 U.S.C. $\$ \S 2000$ e to 2000 e-17 (1988) (equal employment opportunities), have not been held unconstitutional regulations of private individuals' speech or association.

42. Remarks by Nadine Strossen, ACLU General Counsel, responding to Professor Charles Lawrence at the 1989 ACLU Biennial Conference plenary session "Racism on the Rise," June 15, 1989. The "extreme" example cited by Professor Strossen is of a kind in which the Court has been reluctant to concede that the first amendment has any relevance whatsoever. The law is not directed at anything resembling speech or at the views expressed. In such a case the regulation of speech is truly incidental to the regulation of conduct. See also, Strossen, supra note*, at 541-43. Professor Strossen asserts that I "chide[ ] anyone who insists that all racist conduct that includes[ ] an expressive component should be treated alike-namely, as protected speech." Id. at 533. This reading of my position clearly misses my point. I do not contend that all conduct with an expressive component should be treated as unprotected speech. To the contrary, my suggestion that racist conduct amounts to speech is premised upon a unique characteristic of racism-namely its reliance upon the defamatory message of white supremacy to achieve its injurious purpose.

43. All communicative behavior is "100\% action and 100\% expression." Ely, Flag Desecration: A Case Study in the Roles of Categorization and Balancing in First Amendment Analysis, 88 HARv. L. Rev. 1482, 1495-96 (1975). Thus, the distinction between speech and conduct has little determinate content: "[A]ny particular course of conduct may be hung almost randomly on the 
If, for example, John W. Davis, counsel for the Board of Education of Topeka, Kansas, had been asked during oral argument in Brown to state the Board's purpose in educating black and white children in separate schools, he would have been hard pressed to answer in a way unrelated to the purpose of designating black children as inferior. ${ }^{44}$ If segregation's primary goal is to convey the message of white supremacy, then Brown's declaration that segregation is unconstitutional amounts to a regulation of the message of white supremacy. ${ }^{45}$ Properly understood, Brown and its progeny require that the systematic group defamation of segregation be disestablished. 46 Although the exclusion of black children from white schools and the denial of educational resources and association that accompany exclusion can be characterized as conduct, these particular instances of conduct are concerned primarily with communicating the idea of white supremacy. The non-speech elements are byproducts of the main message rather than the message simply a by-product of unlawful conduct. ${ }^{47}$

'speech' peg or the 'conduct' peg as one sees fit." L. TRIBE, AMERICAN ConstrTutional LAW, $\S 12-7$, at 827 (2d ed. 1988). Tribe has suggested that "[m]eaning might be poured into the speechconduct dichotomy by reference to a system of free expression that permits the identification of acts that should be protected by the first amendment." Id.; see also United States v. O'Brien, 391 U.S. 367 (1968). In O'Brien the Court stated that,

[W] hen 'speech' and 'non-speech' elements are combined in the same course of conduct, a sufficiently important governmental interest in regulating the non-speech element can justify incidental limitations on First Amendment freedoms. ... [We] think it clear that a government regulation is sufficiently justified if it is within the constitutional power of the Government; if it furthers an important or substantial governmental interest; the government interest is unrelated to the suppression of free expression; and if the incidental restriction on alleged first amendment freedoms is no greater than is essential to the furtherance of that interest.

Id. at 376-77.

44. The Court is clearest in its articulation of this understanding of the central purpose and meaning of segregation in Loving v. Virginia, 388 U.S. 1 (1966). In striking down the Virginia statute prohibiting interracial marriage, Chief Justice Warren noted that the State's purposes "'to preserve the racial integrity of its citizens,' and to prevent 'the corruption of blood,' 'a mongrel breed of citizens,' and 'the obliteration of racial pride' [were] obviously an endorsement of the doctrine of White Supremacy." Id. at 7 (quoting Naim v. Naim, 197 Va. 80, 90, 87 S.E.2d 749, 756 (1955)).

45. In Plessy v. Ferguson, 163 U.S. 537 (1896), the Court upheld Louisiana's racial segregation of railroad passengers by rejecting the argument that segregation necessarily conveyed a message that blacks were inferior. "If this be so, it is not by reason of anything found in the act, but solely because the colored race chooses to put that construction upon it." Id. at 551. But Brown expressly rejected this rationale. In embracing the notion that "[s]eparate educational facilities are inherently unequal," the Brown Court, 347 U.S. 483, 495 (1954), implicitly adopted the reasoning advanced in Justice Harlan's dissent in Plessy, 163 U.S. at 560 . Justice Harlan argued that provisions requiring separate facilities "in fact proceed on the ground that colored citizens are so inferior and degraded that they eannot be allowed to sit in the public coaches occupied by white citizens. ..." Id.

46. See Black, supra note 37, at 424-26; Lawrence, supra note 40, at 15.

47. This analysis, which acknowledges anti-diserimination law as primarily the regulation of speech, is to be contrasted with the defense of pornography regulation that seeks to characterize the regulation of pornographic speech as the regulation of conduct. See MacKinnon, Not a Moral Issue, 2 YaLe L. \& PoL'y Rev. 321, 340 (1984). 
The public accommodations provisions of the Civil Rights Act of $1964^{48}$ provide another example illuminating why laws against discrimination are also regulation of racist speech. The legislative history and the Supreme Court's opinions upholding the Act establish that Congress was concerned that blacks have access to public accommodations to eliminate impediments to the free flow of interstate commerce, ${ }^{49}$ but this purpose could have been achieved through a regime of separate-but-equal accommodations. Title II goes further; it incorporates the principal of the inherent inequality of segregation, and prohibits restaurant owners from providing separate places at the lunch counter for "whites" and "coloreds." Even if the same food and the same service are provided, separate-but-equal facitities are unlawful. If the signs indicating separate facilities remain in place, then the statute is violated despite proof that restaurant patrons are free to disregard the signs. ${ }^{50}$ Outlawing these signs graphically illustrates my point that anti-discrimination laws are primarily regulations of the content of racist speech.

Another way to understand the inseparability of racist speech and discrimmatory conduct is to view individual racist acts as part of a totality. When viewed in this inanner, white supremacists' conduct or speech is forbidden by the equal protection clause. ${ }^{51}$ The goal of white

48. 42 U.S.C. $\$ \S 2000 \mathrm{a}$ to $2000 \mathrm{a}-6$ (1988).

49. See Heart of Atlanta Motel, Inc. v. United States, 379 U.S. 241 (1964) (upheld Congress' authority under the commerce clause to compel owners of private property to grant access to individuals whom they wish to exclude); Katzenbach v. McClung, 379 U.S. 294 (1964) (same).

50. See D. Bell, Race, Racism and American Law (2nd ed. 1980). Bell suggests that any "decorative changes designed to maintain prior discriminatory policies" may be enjoined as a violation of Title II as a result of United States v. Boyd, 327 F. Supp. 998 (S.D. Ga. 1971). D. BeLL, supra, at 100-01. See also Green v. County School Bd. of New Kent County, 391 U.S. 430 (1968). The Court in Green held that 'in desegregating a dual system a plan utilizing 'freedom of choice' is not an end in itself." Id. at 440.

In the sunmer of 1966 Robert Cover and I were working as summer interns with C.B. King in Albany, Georgia. One day we stopped for lunch at a take-out chicken joint. The establishment was housed in a long diner-like structure with an awning extending frons each of two doors in the side of the building. A sign was painted at the end of each awning. One said, "white" the other "colored." Bob and I entered the "white" side. When the proprietor took my order, I asked if he knew that the signs on his awnings were illegal under Title II of the Civil Rights Act of 1964. He responded, "People can come in this place through any door they want to." What this story makes apparent is that the signs themselves constitute an injury that violates the anti-discrimination principle even when the conduct of denial of access is not present.

51. See Strauder v. West Virginia, 100 U.S. 303 (1880). According to Justice Strong, "The words of the amendnient ... contain a necessary implication of positive immunity, or right ... to the colored race-the right to exemption from unfriendly legislation against them distinctly as coloredexemption from ... discriminations which are steps toward reducing them to the condition of a subject race." Id. at 307-08. Of course the equal protection clause only forbids governmental conduct that purposefully establishes or maintains white supremacy. But see infra notes 57.81 and accompanying text (deseribing how the state action doctrine distorts our understanding of this problen1). 
supremacy is not achieved by individual acts or even by the cumulative acts of a group, but rather it is achieved by the institutionalization of the ideas of white supremacy. The institutionalization of white supremacy within our culture has created conduct on the societal level that is greater than the sum of individual racist acts. The racist acts of millions of individuals are mutually reinforcing and cumulative because the status quo of institutionahized white supremacy reinains long after deliberate racist actions subside..$^{52}$

It is difficult to recognize the institutional significance of white supremacy or how it acts to harm, partially because of its ubiquity. We simply do not see most racist conduct because we experience a world in which whites are supreme as simply "the world." Much racist conduct is considered unrelated to race or regarded as neutral because racist conduct maintains the status quo, the status quo of the world as we have known it. Catharine MacKinnon has observed that "to the extent that pornography succeeds in constructing social reality, it becomes invisible as harm." 53 Thus, pornography "is more act-like than thought-like."54 This truth about gender discrimination is equally true of racism.

Just because one can express the idea or message embodied by a practice such as white supremacy does not necessarily equate that practice with the idea.ss Slavery was an idea as well as a practice, but the Court recognized the inseparability of idea and practice in the institution of slavery when it held the enabling clause of the thirteenth amendinent clothed Congress with the power to pass "all laws necessary and proper for abolishing all badges and incidents of slavery in the United States." 56 This understanding also informs the regulation of speech/conduct in the public accominodations provisions of the Civil Rights Act of 1964 discussed above. When the racist restaurant or hotel owner puts a "whites only" sign in his window, his sign is more than speech. Putting up the

52. Professor Kendall Thomas describes the way in which racism is simultaneously speech (a socially constructed meaning or idea) and conduct by asking us to consider the concept of "race" not as a noun but as a verb. He notes that race is a social construction. The meaning of "black" or "white" is derived through a history of acted-upon ideology. Moreover, the cultural meaning of race continues to be promulgated through millions of ongoing contemporaneous speech/acts. Thus, he says, "we are raced." The social construction of race is an ongoing process. Comments of Kendall Thomas at panel on Critical Race Theory, conference on Frontiers of Legal Thought, Duke Law School, January 26, 1990.

53. C. Mackinnon, Toward a Feminist Theory of the State 204 (1989).

54. Id.

55. Id.

56. The Civil Rights Cases, 109 U.S. 3, 20 (1883) (striking down the Civil Rights Act of 1875 on the ground that the fourteenth amendment did not empower Congress to prohibit racial discrimination by innkeepers, railroads, and places of public amusement); Jones v. Alfred H. Mayer Co., 392 U.S. 409, 439 (1968) (upholding Congress' use of the "badge of servitude" idea to justify federal legislation prohibiting racially discriminatory practices by private persons). 
sign is more than an act excluding black patrons who see the sign. The sign is part of the larger practice of segregation and white supremacy that constructs and maintains a culture in which non-whites are excluded from full citizenship. ${ }^{57}$ The inseparability of the idea and practice of racism is central to Brown's holding that segregation is inherently unconstitutional.

Racism is both $100 \%$ speech and $100 \%$ conduct. ${ }^{58}$ Discriminatory conduct is not racist unless it also conveys the message of white supremacy-unless it is interpreted within the culture to advance the structure and ideology of white supremacy. ${ }^{59}$ Likewise, all racist speech constructs the social reality that constrains the liberty of non-whites because of their race. By limiting the life opportunities of others, this act of constructing meaning also makes racist speech conduct.

\section{B. The Public/Private Distinction}

There are critics who would contend that Brown is inapposite because the equal protection clause only restricts goverument behavior, whereas the first amendment protects the speech of private persons. They say, "Of course we want to prevent the state from defaming blacks, but we must continue to be vigilant about protecting the speech rights, even of racist individuals, from the government. In both cases our concern must be protecting the individual from the unjust power of the state."

At first blush, this position seems persuasive, but its persuasiveness rehes upon the mystifying properties of constitutional ideology. In particular, I refer to the state action doctrine. ${ }^{60}$ By restricting the application of the fourteenth amendment to discrimination implicating the

57. See supra note 50 (story of "white" and "colored" signs).

58. John Ely has made the same observation about all speech. See supra note 43. But I want to do more than merely convey the dilemma one faces in separating out the speech and conduct elements of communicative acts: I want to stress the complete overlap of the idea and practice of racism.

59. For a discussion of how conduct that violates the equal protection clause might be identified by reference to its cultural meaning within the society, see Lawrence, supra note 20, at 355-62.

60. Roughly stated,

[T] he [state action] doctrine holds that although someone may have suffered harmful treatment of a kind that one might ordinarily describe as a deprivation of liberty or a denial of equal protection of the laws, that occurrence excites no constitutional concern unless the proximate active perpetrators of the harm include persons exercising the special authority or power of the government of a state.

Michelman, Conceptions of Democracy in American Constitutional Argument: The Case of Pornography Regulation, 56 TENN. L. REV. 291, 306 (1989). The doctrine embodies the notion in American life and law that racial discrimination ean be accurately and properly divided into two spheres, "public" and "private." See D. BELL, supra note 50, at 104-10. Karl Klare notes that the separation of state and civil society became a centerpiece of all liberal political theory and was important in 
government, the state action rule immunizes private discriminators fron constitutional scrutiny. In so doing, it leaves untouched the largest part of the vast system of segregation in the United States. The Civil Rights Cases, in which this doctrine was firmly estabhished, stands as a inonument preserving American racial discrimination. Although the origin of state action is textual, countervailing values of privacy, freedom of association, and free speech all have been used to justify the rule's exculpation of private racisn1. ${ }^{61}$

In the abstract, the right to make decisions about how we will educate our children or with whom we will associate is an important value in American society. But when we decontextualize by viewing this privacy value in the abstract, we ignore the way it operates in the real world. ${ }^{62}$ We do not ask ourselves, for example, whether it is a value to which all persons have equal access. And we do not inquire about who has the resources to send their children to private school or move to an exclusive suburb. ${ }^{63}$ The privacy value, when presented as an ideal, seeins an appropriate limitation on racial justice because we naively believe that everyone has an equal stake in this value.

the development of American constitutionalism. Klare's analysis shows how the state action limitation of the fourteenth amendment permitted a system of social and economic domination by prohibiting only those evils that could be direetly conneeted to the intentional exercise of state power. Entities such as corporations, universities, and labor unions are treated as private although their actions are public in scope and character. Klare, The Quest for Industrial Democracy and the Struggle Against Racism: Perspectives from Labor Law and Civil Rights Law, 61 OR. L. REv. 157 (1982) (discussion of the structural similarities between the limitations contained in labor law and civil rights law). Klare argues that:

[T] he practices constituting the "private sphere" of social and economic life are inextricably linked to and partially constituted by the rule of law. By the same token law is imbued with, when not captured by, the power relationships of sacial life. The law simply does not stand apart from the hierarchy of social life. Law and politics are implicated in the class and racial domination that characterize American society. There is no "core" or "infrastructure" of social or economic life that can be mcaningfully described without reference to the role of law.

Id. at 183 (footnotes omitted).

61. Thus it is argued that a white family's decision to send its children to private school or to move to a racially exclusive suburb should be accorded respect in spite of the fourteenth amendment's requirement of nondiscrimination because these decisions are part of the right to individual familial autonomy. In this way, the state action rule's rather arbitrary limit on the scope of the antidiscrimination principle is transformed into a right of privacy-which is presented as the constitutional embodiment of an affirmative, neutral, and universally shared value. A new and positive image emerges-an image that has been abstracted from its original context.

62. I do not mean to suggest that privacy or autonomy has no normative value; there is some point at which the balance ought to be struck in its favor after full consideration of the ineguities that might accompany that choice. What is,objectionable about the privacy language that I am discussing here is that it ignores inequities and assumes we all share equally in the value being promoted.

63. The Court's treatment of the abortion controversy provides the most striking example of the fact that the right of autonomous choice is not shared by rich and poor alike. In Roc v. Wade, 410 U.S. 113 (1973), the Court declared, in no uncertain terms, that the right of privacy "is broad enough to encompass a woman's decision whether or not to terminate her pregnancy." Id. at 153. 
The argument that distinguishes private racist speech from the government speech outlawed by Brown suffers from the same decontextualizing ideology. If the government is involved in a joint venture with private contractors to engage in the business of defaming blacks, should it be able to escape the constitutional mandate that makes that business illegal simply by handing over the copyright and the printing presses to its partners in crime? I think not. And yet this is the essence of the position that espouses first amendment protection for those partners.

In an insightful article considering the constitutional implications of government regulation of pornography, Frank Michelman has observed that the idea of state action plays a crucial, if unspoken, role for judges and civil hbertarians who favor an absolute rule against government regulation of private pornographic publications (or racist speech), even when that expression is causative "of effects fairly describable . . . as deprivations of liberty and denials of equal protection of the laws." $64 \mathrm{He}$ notes that judges and civil libertarians would not balance the evils of private subversions of liberty and equal protection against the evils of government censorship because "the Constitution, through the state action doctrine, in effect tells them not to."65 Michelman suggests that the state action doctrine, by directing us to the text of the fourteenth amendment, diverts our attention from the underlying issue-whether we should balance the evils of private deprivations of liberty against the government deprivations of liberty that may arise out of state regulations designed to avert those private deprivations.

When a person responds to the argument that Brown mandates the abohtion of racist speech by reciting the state action doctrine, she fails to consider that the alternative to regulating racist speech is infringement of the claims of blacks to liberty and equal protection. ${ }^{66}$ The best way to

Yet, in Harris v. McRae, 448 U.S. 297 (1980), the Court with equal certainty asserted that "it simply does not follow that a woman's freedom of choice carries with it a constitutional entitlement to the financial resources to avail herself of the full range of protected choices." Id. at 316.

64. See Michelman, supra note 60, at 306-07 (reflecting on the ambiguities in American constitutional legal thought concerning the governmental regulation of pornography).

65. Id.

66. Id. at 307. Michelman further argues that once the constitutional problem is properly posed it is far from obvious that the state commits the forbidden deprivation or denial by choosing the regulatory alternative.

[S]o long as the state can fairly support a judgment that the infringements of liberty and equal protection consequent upon its choice for regulation of pornography are, in some appropriate sense, lesser than the infringements of liberty and equal protection consequent upon the opposite choice to leave pornography unregulated, that pro-regulation choice by the state would seem to come as close as humanly possible to good-faith compliance with the constitutional mandate. For the state simply to disregard the subversions of liberty and equal protection consequent upon a choice not to regulate-to set them aside as of no account-when it knows about those subversions and knows, too, how to avoid them by regulating, is for the state to choose to incur those subversions and thereby to cause them 
constitutionally protect these competing interests is to balance them directly. To invoke the state action doctrine is to circumvent our value judgment as to how these competing interests should be balanced. ${ }^{67}$

The deference usually given to the first amendment values in this balance is justified using the argument that racist speech is unpopular speech, that, hike the speech of civil rights activists, pacifists, and religious and political dissenters, it is in need of special protection from majoritarian censorship. But for over three hundred years, racist speech has been the liturgy of America's leading established religion, the religion of racism. Racist speech remains a vital and regrettably popular characteristic of the American vernacular. ${ }^{68}$ It must be noted that there has not yet been satisfactory retraction of the government-sponsored defamation in the slavery clauses, ${ }^{69}$ the Dred Scott decision, ${ }^{70}$ the black codes, the segregation statutes, and countless other group libels. The injury to blacks is hardly redressed by deciding the government must no longer injure our reputation if one then invokes the first amendment to ensure that racist speech continues to thrive in an unregulated private market. ${ }^{71}$

Consider, for example, the case of McLaurin v. Oklahoma State Regents, ${ }^{72}$ where the University of Oklahoma graduate school, under order

\footnotetext{
by even the strictest notions of legal causation. The issue of the state's liability for the resulting harm thus leaves behind the question of causation, to confront instead the question of justification by countervailing responsibilities, interests, or values (in this case consisting of the pornographer's claims to liberty and equal protection). On this analysis, the state's constitutional obligation would be to compare the constitutional values respectively at risk in the options that it confronts. The corresponding duty of a reviewing court would be to ascertain, within the limits of judicial institutional competence, whether the state has done so responsibly and in good faith.
}

Id. at 307-09 (footnotes omitted).

MacKinnon takes the argument a step farther, arguing that:

The most basic assumption underlying First Amendment adjudication is that, socially, speech is frec.... Frec speech exists. The problem for government is to avoid constraining that which, if unconstrained by government, is frec. This tends to presuppose that whole segments of the population are not systematically silenced socially prior to government action.

MacKinnon, supra note 47 , at 340.

67. Alan Freeman has described how much of civil rights law disguises value conflicts between victim and perpetrator groups by illustrating what is at stake in decontextualized neutral terms like "color blind" and "privacy." Freeman, School Desegregation Law: Promise, Contradiction, Rationalization, in Shades of BRown: New Perspectives on SCHOOL Desegregation 70 (D. Bell ed. 1980).

68. Mari Matsuda gives us a small but powerful sampling of the millions of stories of racist verbal assault that could be told by victims of those assaults. Matsuda, supra note 25, at 2326-31.

69. U.S. ConsT. art. I, § 2, cl. 3; id. § 9, cl. 1; id. art. IV, § 2, cl. 3.

70. Dred Scott v. Sanford, 60 U.S. (19 How.) 393 (1857).

71. If one insists on maintaining the state action distinction, then it might well be argued that under Shelly v. Kramer, 334 U.S. 1 (1948), there is state action when the first amendment is invoked to proteet racist fighting words that would not otherwise be proteeted.

72. 339 U.S. 637 (1950). 
by a federal court to admit McLaurin, a black student, designated a special seat, roped off from other seats, in each classroom, the library, and the cafeteria. The Supreme Court held that this arrangement was unconstitutional because McLaurin could not have had an equal opportunity to learn and participate if he were humiliated and symbolically stigmatized as an untouchable. Would it be any less injurious if all McLaurin's classmates had shown up at the class wearing blackface? Should this symbohic speech be protected by the constitution? Yet, according to a Time magazine report, last fall at the University of Wisconsin "members of the Zeta Beta Tau fraternity staged a mock slave auction, complete with some pledges in blackface."73 More recently, at the same university, white male students trailed black female students shouting, 'I've never tried a nigger before." "74 These young women were no less severely injured than was Mr. McLaurin simply because the University did not directly sponsor their assault. If the University fails to protect them in their right to pursue their education free from this kind of degradation and humiliation, then surely there are constitutional values at stake.

It is a very sad irony that the first instinct of many civil libertarians has been to express concern for possible infringement of the assailants' liberties while barely noticing the constitutional rights of the assailed. Shortly after Brown, many southern communities tried to escape the mandate of desegregation by closing public schools and opening private (white) academies. These attempts to avoid the fourteenth amendment through the privatization of discrimination consistently were invalidated by the courts. ${ }^{75}$ In essence, the Supreme Court held that the defamatory message of segregation would not be insulated from constitutional proscription simply because the speaker was a non-government entity.

The Supreme Court also has indicated that Congress may enact legislation regulating private racist speech. In upholding the public accommodations provisions of Title II of the Civil Rights Act of $1964^{76}$ in Heart of Atlanta Motel v. United States, the Court implicitly rejected the argument that the absence of state action meant that private discriminators were protected by first amendment free speech and associational

73. A Step Toward Civility, TIME, May 1, 1989, at 43.

74. Id.

75. See Griffin v. Prince Edward County School Bd., 377 U.S. 218 (1964) (ordering a county school system reopened; five years earlier it had been closed to avoid desegregation); Norwood $v$. Harrison, 413 U.S. 455 (1973) (preventing a state from lending textbooks to students attending private white academies); see also Runyon v. McCrary, 427 U.S. 160 (1976) (interpreting 42 U.S.C. $\S 1981$ (1988) to outlaw race discrimination by private schools).

76. 42 U.S.C. $\$ \S 2000 \mathrm{a}, 2000 \mathrm{a}-1$ to $2000 \mathrm{a}-6$ (1988). 
rights. ${ }^{77}$ Likewise in Bob Jones University v. United States, ${ }^{78}$ the court sustained the Internal Revenue Service's decision to discontinue tax exempt status for a college with a policy against interracial dating and marriage. The college framed its objection in terms of the free exercise of religion, since their policy was religiously motivated, but the Supreme Court found that the government had "a fundamental, overriding interest in eradicating racial discrimination in education" that "substantially outweighs whatever burden denial of tax benefits"79 placed on the college's exercise of its rehigious beliefs. It is difficult to believe that the University would have fared any better under free speech analysis or if the policy had been merely a statement of principle rather than an enforceable disciplinary regulation. ${ }^{80}$ Regulation of private racist speech also has been held constitutional in the context of prohibition of racedesiguated advertiseinents for employees, home sales, and rentals. ${ }^{81}$

Thus Brown and the anti-discrimination law it spawned provide precedent for my position that the content regulation of racist speech is not only permissible but may be required by the Constitution in certain circumstances. This precedent may not mean that we should advocate the government regulation of all racist speech, but it should give us pause in assuming absolutist positions about regulations aimed at the message or idea such speech conveys. If we understand Brown-the cornerstone of the civil rights movement and equal protection doctrine-correctly, and if we understand the necessity of disestablishing the systein of signs and symbols that signal blacks' inferiority, then we should not proclaim that all racist speech that stops short of physical violence inust be defended.

\section{RAcist Speech as the Functional Equivalent of FIGHTING WORDS}

Much recent debate over the efficacy of regulating racist speech has focused on the efforts by colleges and universities to respond to the burgeoning incidents of racial harassment on their campuses. At Stanford,

77. Heart of Atlanta Motel, Inc. v. United States, 379 U.S. 241, 258 (1964); see also Roberts v. United States Jaycees, 468 U.S. 609, 624 (1984) (Court upheld the public accommodations provision of the Minnesota Human Rights Act). The Roberts Court explicitly rejected the freedom of association argument stating that "[t]he right to associate for expressive purposes is not, however, absolute. Infringements on that right may be justified by regulations adopted to serve compelling state interests, unrelated to the suppression of ideas, that cannot be achieved through mcans signifieantly less restrictive of associational freedoms." Id. at 623.

78. 461 U.S. 574, 595 (1983).

79. Id. at 604 .

80. Id.; see also Runyon v. McCrary, 427 U.S. 160, $173-75$ (1976) (interpreting 42 U.S.C. $\S 1981$ (1988) to outlaw race discrimination by private schools).

81. Pittsburgh Press Co. v. Pittsburgh Comm'n on Human Relations 413 U.S. 376 (1973) (upholding the regulation of sex designated "Help Wanted" advertising). 
where I teach, there has been considerable controversy over the questions whether racist and other discrimmatory verbal harassment should be regulated and what form that regulation should take. Proponents of regulation have been sensitive to the danger of inhibiting expression, and the current regulation (which was drafted by my colleague Tom Grey) manifests that sensitivity. It is drafted somewhat more narrowly than I would have preferred, leavimg unregulated hate speech that occurs in settings where there is a captive audience, speech that I would regulate. But I largely agree with this regulation's substance and approach..$^{82} \mathrm{I}$ include it here as one example of a regulation of racist speech that I would argue violates neither first amendment precedent nor principle. The regulation reads as follows:

Fundamental Standard Interpretation: Free Expression and Discriminatory Harassment

1. Stanford is committed to the principles of free inquiry and free expression. Students have the right to hold and vigorously defend and promote their opinions, thus entering them into the life of the University, there to flourish or wither according to their merits. Respect for this right requires that students tolerate even expression of opinions which they find abhorrent. Intimidation of students by other students in their exercise of this right, by violence or threat of violence, is therefore considered to be a violation of the Fundamental Standard.

2. Stanford is also committed to principles of equal opportunity and non-discrimination. Each student has the right to equal access to a Stanford education, without discrimination on the basis of sex, race, color, handicap, religion, sexual orientation, or national and ethnic origin. Harassment of students on the basis of any of these characteristics contributes to a hostile environment that makes access to education for those subjected to it less than equal. Such discriminatory harassment is therefore considered to be a violation of the Fundamental Standard.

3. This interpretation of the Fundamental Standard is intended to clarify the point at which protected free expression ends and prohibited discriminatory harassment begins. Prohibited harassment includes discriminatory intimidation by threats of violence, and also includes personal vilification of students on the basis of their sex, race, color, handicap, religion, sexual orientation, or national and ethnic origin.

4. Speech or other expression constitutes harassment by personal vilification if it:

82. I supported a proposal which would have been broader in scope by prohibiting speech of this nature in all common areas, excepting organized and announced rallies and speeches. It would have been narrower in its protection in that it would not have protected persons who were vilified on the basis of their membership in dominant majority groups. 
a) is intended to insult or stigmatize an individual or a small number of individuals on the basis of their sex, race, color, handicap, religion, sexual orientation, or national and ethnic origin; and

b) is addressed directly to the individual or individuals whom it insults or stigmatizes; and

c) makes use of insulting or "fighting" words or non-verbal symbols.

In the context of discriminatory harassment by personal vilification, insulting or "fighting" words or non-verbal symbols are those "which by their very utterance inflict injury or tend to incite to an immediate breach of the peace," and which are commonly understood to convey direct and visceral hatred or contempt for human beings on the basis of their sex, race, color, handicap, religion, sexual orientation, or national and ethnic origin. ${ }^{83}$

This regulation and others like it have been characterized in the press as the work of "thought police," 84 but it does nothing more than prohibit intentional face-to-face insults, a form of speech that is unprotected by the first amendment. When racist speech takes the form of face-to-face insults, catcalls, or other assaultive speech aimed at an individual or small group of persons, then it falls within the "fighting words" exception to first amendment protection. ${ }^{85}$ The Supreme Court has held

83. Fundamental Standard Interpretation: Free Expression and Discriminatory Harassment, adopted by Stanford University June 1990.

It is important to recognize that this regnlation is not content neutral. It prohibits "discriminatory harassment" rather than just plain harassment and it regulates only discriminatory harassment based on "sex, race, color, handicap, religion, sexual orientation, and national or ethnic origin." It is arguably viewpoint neutral with respect to these categories, although its reference to "words . . . which by their very utterance inflict injury ... and which are commonly understood to convey direct and visceral hatred or contempt" probably means that there will be many more epithets that refer to subordinated groups than there will be words that refer to superordinate groups covered by the regulation.

84. Numerous news commentators have labeled as censorship any attempt to regulate verbal harassment: "Stanford's program of speech patrol is hardly the worst . . . " Leo, Legal Cornercutting Slices Away Civil Liberries, Rocky Mountaiu News, June 21, 1989, at 11, col. 6; "[Lawrence's argument] exemplifies the ongoing attempt to give intellectual respectability to the spreading movement of censorship by liberals on campuses." Will, supra note 19; "This is not the first time in recent years that some on the left have sought to silence those who disagree with them." Dembart, supra note 17.

85. The flghting words doctrine requires that the words be "direeted to the person of the hearer." Cohen v. California, 403 U.S. 15, 20 (1971). This requirement strikes a balance between our concern for protecting the individual from unavoidable personalized attack (one is not given an opportunity to avoid the speech by averting the eyes or leaving the room) and our concern for allowing space for even the most offensive speech in a public forum ("one man's vulgarity is another's lyric," id. at 25). I would argue that the face-to-face requirement be expanded in the case of racist verbal assaults to include those words that are intentionally spoken in the presence of members of the denigrated group. See infra notes 87-103 and accompanying text. 
that words that "by their very utterance inflict injury or tend to incite an immediate breach of the peace"86 are not constitutionally protected.

Face-to-face racial insults, like fighting words, are undeserving of first amendment protection for two reasons. The first reason is the immediacy of the injurious impact of racial insults. The experience of being called "nigger," "spic," "Jap," or "kike" is like receiving a slap in the face. The injury is instantaneous. There is neither an opportunity for intermediary reflection on the idea conveyed ${ }^{87}$ nor an opportunity for responsive speech. The harm to be avoided is both clear and present. The second reason that racial insults should not fall under protected speech relates to the purpose underlying the first amendment. If the purpose of the first aniendment is to foster the greatest amount of speech, then racial insults disserve that purpose. Assaultive racist speech functions as a preemptive strike. The racial invective is experienced as a blow, not a proffered idea, and once the blow is struck, it is unlikely that dialogue will follow. Racial insults are undeserving of first amendment protection because the perpetrator's intention is not to discover truth or initiate dialogue but to injure the victim. ${ }^{88}$

The fighting words doctrine anticipates that the verbal "slap in the face" of insulting words will provoke a violent response with a resulting breach of the peace. When racial insults are hurled at minorities, the response may be silence or flight rather than a fight, but the preeinptive effect on further speech is just as complete as with fighting words. ${ }^{89}$ Women and minorities often report that they find theinselves speechless in the face of discriminatory verbal attacks. This inability to respond is not the result of oversensitivity among these groups, as some individuals who oppose protective regulation have argued. Rather, it is the product of several factors, all of which reveal the non-speech character of the initial preemptive verbal assault. The first factor is that the visceral emotional response to personal attack precludes speech. Attack produces an instinctive, defensive psychological reaction. Fear, rage, shock, and flight all interfere with any reasoned response. Words like "nigger," "kike," and "faggot" produce physical symptoms that temporarily disable the victim, and the perpetrators often use these words with the intention of

86. Chaplinsky v. New Hampshire, 315 U.S. 568, 572 (1942).

87. A defining attribute of speech is that it appeals first to the mind of the hearer who can evaluate its truth or persuasiveness. The use of racial epithets lacks this quality; it is a form of "violence by speech." See J. Denver \& J. Powell, Caliban's Complaint: Racist Speech and the First Amendment, (unpublished manuscript) (available from author).

88. See Arkes, supra note 28, at 331; Delgado, supra note 28, at 175.

89. It should not be necessary to urge victims of these insulting attacks to carry arms so that the "fighting words" rationale of these assaults can be more easily perceived by whites. 
producing this effect. Many victims do not find words of response until well after the assault when the cowardly assaulter has departed.

A second factor that distinguishes racial insults from protected speech is the preemptive nature of such insults-the words by which to respond to such verbal attacks may never be forthcoming because speech is usually an inadequate response. When one is personally attacked with words that denote one's subhuman status and untouchability, there is little (if anything) that can be said to redress either the emotional or reputational injury. This is particularly true when the message and meaning of the epithet resonates with beliefs widely held in society. ${ }^{90}$ This preservation of widespread beliefs is what makes the face-to-face racial attack more likely to preempt speech than are other fighting words. The racist name-caller is accompanied by a cultural chorus of equally demeanimg speech and symbols. ${ }^{91}$

The subordinated victim of fighting words also is silenced by her relatively powerless position in society. Because of the significance of power and position, the categorization of racial epithets as "fighting words" provides an inadequate paradigm; instead one must speak of their "functional equivalent."92 The fighting words doctrine presupposes an

90. I have discussed this phenomena in some detail in two articles that explore the nature of the injury of segregation and other racially stigmatizing actions. Segregation and other forms of racist speech injure victims because of their dehumanizing and excluding message. But each individual message gains its power because of the cumulative and reinforcing effect of countless similar messages that are conveyed in a society where racism is ubiquitous. See Lawrence, supra note 40, at 33-40; Lawrence, supra note 20; see also Karst, The Costs of Motive-Centered Inquiry, 15 SAN DIEGo L. REv. I163, 1163-66 (1978) (constitutional equal protection doctrine should focus on the pervasive social problem of racial inequality).

91. Mari Matsuda has noted that in framing a legal response to racist speech one must consider its role within the structural reality of racism in America.

The implements of racism include: 1. Violence and Genocide; 2. Racial hate messages, disparagement, and threats; 3. Overt disparate treatment; and 4. Covert disparate treatment....

...

From the victim's perspective, all of these implements inflict wounds, wounds that are neither random nor isolated. Gutter racism, parlor racism, corporate racism, and government racism work in coordination, reinforcing existing conditions of domination.

Matsuda, supra note 25, at 2332-35.

92. Some civil libertarians will respond to my use of the "fighting words" dóctrine by arguing that the doctrine itself is not good law. They will note that the reasoning in Chaplinsky v. New Hampshire, 315 U.S. 568 (1942), has been implicitly abandoned, see Strossen, supra note *, at 509. 10. Civil libertarians have always been critical of a doctrine which allows those who object to unpopular speech to exercise a veto on that speech by the threat of resort to violence. In response to the first point, I would note that at least as recently as Cohen v. California, 403 U.S. 15 (1971), the Court indicated the continuing vitality of Chaplinsky in the context of face-to-face insults. In Cohen, the Court held that "the states are free to ban the simple use, without a demonstration of additional justifying circumstances, of so-called 'fighting words,' those personally abusive epithets which, when addressed to the ordinary citizen, are, as a matter of common knowledge, inherently likely to provoke violent reaction." Id. at 20 . More importantly, I am in substantial agreement with the civil 
encounter between two persons of relatively equal power who have been acculturated to respond to face-to-face insults with violence. The fighting words doctrine is a paradigm based on a white male point of view. ${ }^{93}$ In most situations, minorities correctly perceive that a violent response to fighting words will result in a risk to their own life and limb. Since minorities are likely to lose the fight, they are forced to remain silent and submissive. ${ }^{94}$ This response is most obvious when women submit to sexually assaultive speech or when the racist name-caller is in a more powerful position-the boss on the job or the mob. Certainly, we do not expect the black women crossing the Wisconsin campus to turn on their tormentors and pummel them. Less obvious, but just as significant, is the effect of pervasive racial and sexual violence and coercion on individual

libertarians who would not cease to protect speech that increases the propensity to violence of those who oppose the speech. Paradoxically, it is this clear and present danger of violence rationale that Professor Strossen cites as the part of the fighting words doctrine that remains good law. See Strossen, supra note *, at 509-10. It also is worth noting that virtually every case in which the Court reversed the conviction of persons charged with using offensive language directed at an individual, the reversal was based on the overbreadth of the statute and the potentially offended party was in a position of relative power when compared with the speaker. See, e.g., Rosenfeld v. New Jersey, 408 U.S. 901 (1972); Lewis v. New Orleans, 408 U.S. 913 (1972); Brown v. Oklahoma, 408 U.S. 914 (1972). A majority of the Supreme Court was willing to vacate and remand those convictions for use of offensive language. But there is an alternative rationale for the "fighting words" doctrine that is more sound. Speech that precmpts further speech rather than inviting response does not serve the purposes of the first amendment and is therefore less deserving of protection. Furthermore, I believe that racists' fighting words and other face-to-face verbal assaults against persons from subordinated groups more closely fit this rationale than do garden variety fighting words.

93. The fighting words doctrine captures the "macho" quality of male discourse. It is accepted, justifiable, and even praiseworthy when "rcal men" respond to personal insult with violence. (Presidential candidate George Bush did well to emulate the most macho, and not coincidentally violent, of movie stars, Clint Eastwood, when he repeatedly used the phrase, "Read my lips!" Any teenage boy will tell you the subtext of this message: "I've got nothing else to say about this and if you don't like what I'm saying we can step outside.") The figlting words doctrine's responsiveness to this "male" stance in the world and its blindness to the cultural experience of women is another example of how "neutral" prineiples of law often reflect the values of those who are dominant. Black males also are well aware of the double standard that our culture applies to black and white men in responding to insult. Part of the culture of racial domination through violence-a culture of dominance that manifested itself in thousands of lynchings in the south and more recently in the raeial violence at Howard Beach and Bensonhurst-is the paradoxical expectation on the part of whites that black males will accept insult from whites without protest, yet they will become violent without provocation. These expectations combine two assumptions: First, that blacks as a group-and especially black males-are more violent and, second, that, as inferior persons, blacks have no right to feel insulted. One can only imagine the response of universities if black males started to respond to racist fighting words by beating up white students.

94. It is both uncommon and unlikely that whites will insult minorities with racial epithets in contexts where they are outnumbered or overmatched. Racial name calling is usually a sport engaged in by cowards who are certain of their ability to win the figlt before they inflict the first blow. 
members of subordinated groups who must learn the survival techniques of suppressing and disguising rage and anger at an early age. ${ }^{95}$

One of my students, a white, gay male, related an experience that is quite instructive in understanding the inadequacy and potential of the "fighting words" doctrine. In response to my request that students describe how they experienced the injury of racist speech, Michael told a story of being called "faggot" by a man on a subway. His description included all of the speech inhibiting elements I have noted previously. He found himself in a state of semi-shock, nauseous, dizzy, unable to muster the witty, sarcastic, articulate rejomder he was accustoined to making. He suddenly was aware of the recent spate of gay-bashing in San Francisco, and how inany of these had escalated from verbal encounters. ${ }^{96}$ Even hours later when the shock resided and his facility with words returned, he realized that any response was inadequate to counter the hundreds of years of societal defamation that one word- "faggot"carried with it. Like the word "nigger" and unlike the word "liar," it is not sufficient to deny the truth of the word's application, to say, "I am not a faggot." One must deny the truth of the word's meaning, a ineaning shouted from the rooftops by the rest of the world a million times a day. ${ }^{97}$ Although there are inany of us who constantly and in inyriad ways seek to counter the lie spoken in the meaning of hateful words like "nigger" and "faggot," it is a nearly impossible burden to bear when one encounters hateful speech face-to-face.

But there was another part of my discussion with Michael that is equally instructive. I asked if he could reinember a situation when he had been verbally attacked with reference to his membership in a superordinate group. Had he ever been called a "honkie," a "chauvinist pig," or "mick"? (Michael is from a working class Irish family in Boston.) He said that he had been called some version of all three and that although

95. For a discussion of submissiveness as a psychological defense, see Guthrie, White Racism and Its Impact on Black and White Behavior, 1 Journal OF NON-White CONCERnS IN PersonNel and Guidance 144 (1973). See also C. Mackinnon, Sexual Harassment of Working Women: A Case of Sex Discrimination (1979); S. Brownmiller, Against Our Will: MEN, WOMEN AND RAPE (1975).

96. The National Gay and Lesbian Task Force includes verbal harassment among its categories of anti-gay violence. Hatfield, Attacks on Gays Rising, San Francisco Examiner, June 7, 1989, at A10, col. 2. Matsuda notes that racial violence is typically preceded by racist propaganda. Matsuda, supra note 25 , at $2335-41$.

97. See Bowers v. Hardwick, 478 U.S. 186 (1986). Chief Justice Burger, in his now infamous concurrence, quoting Blackstone's characterization of sodomy "as an offense of 'deeper malignity" than rape, a heinous act 'the very mention of which is a disgrace to human nature," " urged the Court to defer to the "millennia of moral teaching." Id. at 197. Mary Dunlap has called this one of the "gifts" of the Hardwick case-the recorded and published admission by the Supreme Court that we live in a profoundly homophobic nation. Remarks by Mary Dunlap, Stanford Law School symposium on Bowers v. Hardwick (May 8, 1989). 
he found the last one more offensive than the first two, he had not experienced-even in that subordinated role-the same disorienting powerlessness he had experienced when attacked for his membership in the gay community. The question of power, of the context of the power relationships within which speech takes place, must be considered as we decide how best to foster the freest and fullest dialogue within our communities. It is apparent that regulation of face-to-face verbal assault in the manner contemplated by the Stanford provision ${ }^{98}$ will make room for more speech than it chills. The provision is clearly within the spirit, if not the letter, of existing first amendment doctrine.

The proposed Stanford regulation, and indeed regulations with considerably broader reach, can be justified as necessary to protect a captive audience from offensive or injurious speech. Courts have held that offensive speech may not be regulated in public forums such as streets and parks where a listener may avoid the speech by moving on or averting his eyes, ${ }^{99}$ but the regulation of otherwise protected speech has been permitted when the speech invades the privacy of the unwilling listener's home or when the unwilling listener cannot avoid the speech. ${ }^{100}$ Racists posters, flyers, and graffiti in dorms, classrooms, bathrooms, and other common living spaces would fall within the reasoning of these cases. Minority students should not be required to remain in their rooms to avoid racial assault. ${ }^{101}$ Minimally, they should find a safe haven in their dorms and other common rooms that are a part of their daily routine. I would argue that the university's responsibility for ensuring these students received an equal educational opportunity provides a compelling justification for regulations that ensure them safe passage in all common

98. See supra note 83 and accompanying text.

99. See Cohen v. California, 403 U.S. 15, 21 (1971) (holding that the state could not prohibit spech merely because it is offensive); Erznoznik v. City of Jacksonville, 422 U.S. 205, 209 (1975) (overturning a city ordinance that deterred drive-in theaters from showing movies containing nudity).

100. See Kovacks v. Cooper, 336 U.S. 77, 86 (1949) (right to free speech not abridged by city ordinance outlawing use of soundtracks on city streets); FCC v. Pacifica Found., 438 U.S. 726, 748 (1978) (limited first amendment protection of broadcasting that extends into privacy of home); Rowan v. United States Post Office Dep't, 397 U.S. 728, 736 (1970) (unwilling reeipient of sexually arousing material had right to instruct Postmaster General to cease mailings to protect recipient from unwanted communication of "ideas").

101. At Stanford two white students posted a Sambo-like defacement of a Beethoven poster on a bulletin board outside of a black student's room in the black theme dorm. The University's office of general counsel held that the offending students could not be prosecuted under the University's fundamental standard because their actions constituted proteeted speech. Nowhere in their opinion did they mention the captive audience cases or the fact that the black students in this dorm might have a justifiable expectation that they would not be subjeeted to this sort of vilification in what was now their home. Schwartz \& Brest, First Amendment Principles and Prosecution for Offensive Expression under Stanford's Student Disciplinary System, Stanford Daily, Feb. 8, 1989, at 9, col. 1. 
areas. A black, latino, Asian or Native American student should not have to risk being the target of racially assaulting speech every time she chooses to walk across campus. ${ }^{102}$ The regulation of vilifying speech that cannot be anticipated or avoided would not preclude announced speeches and rallies where minorities and their allies would have an opportunity to organize counter-demonstrations or avoid the speech altogether. ${ }^{103}$

\section{KNOWING THE INJURY AND STRIKING THE BALANCE: UNDERSTANDING WHAT IS AT STAKE IN RACIST SPEECH CASES}

I argued in Part II that narrowly drafted regulations of racist speech that prohibit face-to-face vilification and protect captive audiences from verbal and written harassment can be defended within the confines of existing first amendment doctrine. In this Part, I will argue that many civil libertarians who urge that the first amendment prohibits any regulation of racist speech have given inadequate attention to the testimony of individuals who have experienced injury from such speech-these civil libertarians fail to comprehend both the nature and extent of the injury inflicted by racist speech. I further urge that understanding the injury requires reconsideration of the balance that must be struck between our concerns for racial equality and freedom of expression.

The argument most commonly advanced against the regulation of racist speech goes something like this: We recognize that minority groups suffer pain and injury as the result of racist speech, but we must allow this hatemongering for the benefit of society as a whole. Freedom of speech is the lifeblood of our democratic system. ${ }^{104}$ It is a freedom

102. According to Howard J. Ehrlich of the National Institute Against Prejudice and Violence, "[b]etween $20 \%$ and $25 \%$ of all minority students on campus have been victimized at least once during an academic year." Rieehmann, Colleges Tackle Increase in Racism on Campuses, L. A. Times, Apr. 30, 1989, Part I, at 36, col. 1. See also H. EhrLICH, supra note 18, at 41-72.

103. Racist speakers planning organized events such as the Nazis march in Skokie or a spokesperson for the Klan would not be precluded from obtaining a permit to march or speak at designated times and places.

104. Mari Matsuda sets forth the core ideas upon which civil libertarians base their arguments: Democratic, representative government presumes that people are free to think and say whatever they might, even the unthinkable. They can advocate the end of democracy. We risk the chance that they will prevail because to give government the power to control expression is an even greater threat. ... Thus, under our system, there is "no such thing as a false idea." ... When all ideas are voiced freely, we have the greatest chance that the right result will obtain.

We have no way of knowing what the right results are in advance. . . . We have no basis for distinguishing good from bad ideas, the only logical choice is to protect all ideas.

Matsuda, supra note 25, at 2349-50 (quoting Gertz v. Robert Welch, Inc., 418 U.S. 323, 339 (1924)) (footnotes omitted). This reasoning might suggest that possible truth is a reason for protecting racist speech. But, "[t]o their credit most civil libertarians avoid this rationale, arguing instead that racist lies must be protected in order to preservc frec speech for all." Id. at 2350 n.155. 
that enables us to persuade others to our point of view. Free speech is especially important for minorities because often it is their only vehicle for rallying support for redress of their grievances. We cannot allow the public regulation of racist invective and vilification because any prohibition precise enough to prevent racist speech would catch in the same net forms of speech that are central to a democratic society. 105

Whenever we argue that racist epithets and vilification must be allowed, not because we would condone them ourselves but because of the potential danger that precedent would pose for the speech of all dissenters, ${ }^{106}$ we are balancing our concern for the free flow of ideas and the democratic process and our desire to further equality. This kind of categorical balance is struck whenever we frame any rule-even an absolute rule. ${ }^{107}$ It is important to be conscious of the nature and extent of injury to both concerns when we engage in this kind of balancing. In this case, we must place on one side of the balance the nature and extent of the injury caused by racism. We also must be very careful, in weighing the potential harm to free speech, to consider whether the racist speech we propose to regulate is advancing or retarding the values of the first amendment.

\section{A. Understanding the Injury Inflicted by Racist Speech}

There can be no meaningful discussion about how to reconcile our commitment to equality and our commitment to free speech until we acknowledge that racist speech inflicts real liarm and that this harm is far

105. There are two additional commonly advanced arguments against regulating racist speech. First, that such regulation is content-based government censorship of political speech. See, e.g. Strossen, supra note *, at 534 (referring to the traditional prohibition on any content based regula. tions); $i d$. at 536 (noting that "if the freedom of speech is weakened for one person, group, or message, then it is no longer there for others"). See also L. TR1BE, supra note $43, \S 12-8$, at 832. Second, suppressing such speech will only force it underground and will do nothing to curb the more clandestine or subtle forms of discrimination, but when these ideas are given "fresh air" we can organize against them and ultimately they will be rejected. See, e.g., Strossen, supro note *, at 554 (arguing that "censored speech becomes more appealing and persuasive to many listeners merely by virtue of the censorship"); id. at 560 (Regulation will "drive some racist thought and expression underground, where it would be more difficult to respond to such speech and the underlying attitudes it expresses.").

106. This precedent need not take the form of case law, it might also include general societal tolerance for the suppression of speech.

107. For example the "actual malice" rule of New York Times v. Sullivan, 376 U.S. 254 (1964), and Gertz v. Robert Welch, Inc., 418 U.S. 323 (1974), balances the state's interest in compensating public figures or private individuals for injury to their reputation against the first amendment interest in protecting matters of public interest. When public officials or public figures are involved, the rule shifts the balance struck between these two interests in a direction that provides more room for speech. This shift recognizes both the concern for maximizing speech on public issues and the fact that public figures are more able to gain access to the media and respond than are private individuals. 
from trivial. ${ }^{108}$ I should state that more strongly: To engage in a debate about the first amendment and racist speech without a full understanding of the nature and extent of the harm of racist speech risks making the first amendment an instrument of domination rather than a vehicle of liberation. ${ }^{109}$ Not everyone has known the experience of being victimized by racist, misogynist, and homophobic speech, and we do not share equally the burden of the societal harm it inflicts. Often we are too quick to say we have heard the victims' cries when we have not; we are too eager to assure ourselves we have experienced the same injury, and therefore we can make the constitutional balance without danger of mismeasurement. For many of us who have fought for the rights of oppressed minorities, it is difficult to accept that-by underestimating the injury from racist speech-we too imight be implicated in the vicious words we would never utter. Until we have eradicated racism and sexism and no longer share $\mathrm{m}$ the fruits of those forms of domination, we cannot justly strike the balance over the protest of those who are dormnated. My plea is simply that we histen to the victims.

Members of my own family were involved im a recent incident at a private school in Wilmington, Delaware that taught me inuch about both the nature of the injury racist speech inflicts and the lack of understanding many whites have of that mjury.

As a good Quaker school dedicated to a deep cominitınent to and loving concern for all the meinbers of its community, Wilmington Friends School also had been a haven for white families fleeing the court ordered desegregation of the Wilmington public schools. In recent years, the school strove to meet its comimitment to human equality by enrolling a small (but significant) group of mmority students and hiring an even smaller number of black faculty and staff. My sister Paula, a gifted, passionate, and dedicated teacher was the principal of the lower school. Her sons attend the high school. My brother-in-law, John, teaches geology at the University of Delaware. He is a strong, quiet, loving man, and he is white. My sister's family had moved to Wilmington shouldering the extra burdens and anxieties borne by an interracial family moving to a town where, not long ago, the defamatory message of segregation graced the doors of bathrooms and restaurants. Within a year they had made

108. Mari Matsuda has made an important initial effort in relating some of the millions of stories that must be told before we can fully understand the nature and effect of the injury inflicted by racist speech. By placing these "victim's stories" beside the story told in traditional first amendment doctrine, Professor Matsuda demonstrates how one's analysis of an appropriate and just response to racist speech is impoverished by the omission of the victim's accounts. See Matsuda, supra note 25, at 2326-41.

109. See infra notes 153-55 and accompanying text (referring to my discussion of taxation without representation). 
their place as well-loved and respected members of the community, particularly the school community, where Paula was viewed as a godsend and my nephews had made many good friends.

In May of their second year in Wilmington, an incident occurred that shook the entire school community but was particularly painful to my sister's family and others who found themselves the objects of hateful speech. In a letter to the school community explaining a decision to expel four students, the school's headmaster described the incident as follows:

On Sunday evening, May 1, four students in the senior class met by prearrangement to paint the soccer kickboard, a flat rectangular structure, approximately $8 \mathrm{ft}$. by $25 \mathrm{ft}$., standing in the midst of the Wilmington Friends School playing fields. They worked for approximately one hour under bright moonlight and then went home.

What confronted students and staff the following morning, depicted on the kickboard, were racist and anti-Semitic slogans and, most disturbing of all, threats of violent assault against one clearly identified member of the senior class. The slogans written on the kickboard included "Save the land, join the Klan," and "Down with Jews"; among the drawings were at least twelve hooded Ku Klux Klansmen, Nazi swastikas, and a burning cross. The most frightening and disturbing depictions, however, were those that threatened violence against one of our senior black students. He was drawn, in cartoon figure, identified by his name, and his initials, and by the name of his mother. Directly to the right of his head was a bullet, and farther to the right was a gun with its barrel directed toward the head. Under the drawing of the student, three $\mathrm{Ku} \mathrm{Klux}$ Klansmen were depicted, one of whom was saying that the student "dies." Next to the gun was a drawing of a burning cross under which was written "Kill the Tarbaby."110

When I visited my sister's family a few days after this incident, the injury they had suffered was evident. The wounds were fresh. My sister, a care-giver by nature and vocation, was clearly in need of care. My nephews were quiet. Their faces betrayed the aftershock of a recently inflicted blow and a newly discovered vulnerability. I knew the pain and scars were no less enduring because the injury had not been physical. And when I talked to my sister, I realized the greatest part of her pain came not from the incident itself but rather from the reaction of white parents who had come to the school in unprecedented numbers to protest the offending students' expulsion. "It was only a prank." "No one was physically attacked." "How can you punish these kids for mere words, mere drawings." Paula's pain was compounded by the failure of these people, with whoin she had lived and worked, to recognize that she had

110. Letter from Dulany $O$. Bennett to parents, alumni, and friends of the Wilmington Friends School (May 17, 1988). 
been hurt, to understand in even the most limited way the reality of her pain and that of her family.

Many people called the incident "isolated." But black folks know that no racial incident is "isolated" in America. That is what makes the incidents so horrible, so scary. It is the knowledge that they are not the isolated unpopular speech of a dissident few that makes them so frightening. These incidents are manifestations of an ubiquitous and deeply ingrained cultural belief system, an American way of hife. ${ }^{111}$ Too often in recent months, as I have debated this issue with friends and colleagues, I have heard people speak of the need to protect "offensive" speech. The word offensive is used as if we were speaking of a difference in taste, as if I should learn to be less sensitive to words that "offend" ine."12 I cannot help but believe that those people who speak of offense-those who argue that this speech must go unchecked-do not understand the great difference between offense and injury: They have not known the injury iny sister experienced, have not known the fear, vulnerability, and shame experienced by the Wisconsin coeds. There is a great difference between the offensiveness of words that you would rather not hear-because they are labeled dirty, impolite, or personally demeaning-and the injury inflicted by words that remind the world that you are fair game for physical attack, evoke in you all of the millions of cultural lessons regarding your inferiority that you have so painstakingly repressed, and imprint upon you a badge of servitude and subservience for all the world to see. It is instructive that the chief proponents for sanctioning people who inflict these injuries are women and people of color, and there are few among these groups who take the absolutist position that any regulation of this speech is too much. ${ }^{113}$

111. Lawrence, supra note 20, at 330 ("[R]acism in America is much more complex than either the conscious conspiracy of a power elite or the simple delusion of a few ignorant bigots. It is part of our common historical experience and, therefore, a part of our culture.").

112. Cohen v. California, 403 U.S. 15 (1971 (holding that the state could not excise, as offensive conduct, particular epithets from public discourse) and FCC v. Pacifica Found., 438 U.S. 726 (1978) (upholding an FCC sanction against a radio station that broadcast an obscene monologue) are often cited at this point in the discussion. I think that Cohen was rightly decided and that the Court was wrong in Pacifica-curse words may shock and offend but they do not constitute a direct attack on the humanity of an individual or group. Moreover, curse words such as "shit" and "fuck" do not signal a set of beliefs concerning the inferiority, untouchability or legitimacy of exploiting a group that is subjected to systematic subordination. The exception to this, of course, is when the degradation of a particular subordinated group is contained in the meaning of the curse word, such as the word "cocksucker."

113. When I presented an early version of this essay as a speech at the biennial convention of the ACLU, the support for my position from minority delegates was virtually unanimous. In the ensuing plenary session, I do not recall a single minority delegate who spoke in opposition to the resolution that sought to frame a policy based on my paper's recommendations. 
Again, Brown v. Board of Education is a useful case for our analysis. Brown is helpful because it articulates the nature of the injury inflicted by the racist message of segregation. When one considers the injuries identified in the Brown decision, it is clear that racist speech causes tangible injury, and it is the kind of injury for which the law commonly provides, and even requires, redress.

Psychic mjury is no less an injury than being struck in the face, and it often is far more severe. ${ }^{14}$ Brown speaks directly to the psychic injury inflicted by racist speech in notimg that the syinbolic message of segregation affected "the hearts and minds" of Negro children "in a way unhikely ever to be undone."115 Racial epithets and harassment often cause deep emotional scarring, and feelings of anxiety and fear that pervade every aspect of a victim's life. Many victims of hate propaganda have experienced physiological and emotional symptoins ranging froin rapid pulse rate and difficulty in breathing, to nightınares, post-traumatic stress disorder, psychosis and suicide. ${ }^{116}$

A second injury identified in Brown, and present in iny exainple, is reputational injury. "[L]ibelous speech was long regarded as a form of personal assault ... that governinent could vindicate ... without running afoul of the Constitution."117 Although New York Times v. Sullivan and its progeny have subjected much defamatory speech to constitutional scrutiny - on the reasoning that "debate on public issues should be uninhibited, robust and wide-open" 118 and should not be "chilled" by the

114. See Fisher v. Carousel Motor Motel, Inc., 424 S.W.2d 627, 630 (Tex. 1967) (award of $\$ 900$ for racial slur on assault and battery grounds upheld; battery protects dignity as well as physical security); Alcorn v. Anbro Eng'g, Inc., 2 Cal. 3d 493, 498, 468 P.2d 216, 218, 86 Cal. Rptr. 88, 90 (1970) (use of "niggers" sufficient to state a cause of action for "extreme and outrageous" intentional infliction of emotional stress); Agarwal v. Johnson, 25 Cal. 3d 932, 944-46, 603 P.2d 58, 66, 160 Cal. Rptr. 141, 148-49 (1979) (same).

115. Brown v. Board of Educ., 347 U.S. 483, 494 (1954).

116. See Matsuda, supra note 25 , at 2335-41 (physical and psychological harm of racist hate speech is significant). The effects of racial prejudice include displaced aggression, avoidance, retreat, and withdrawal, alcoholism and suicide. H. Kitano, RACE Relations 69-85 (2d ed. 1974). See also Delgado, supra note 28, at 137-39 (noting, inter alia, high blood pressure, loss of self-worth, and special harm to children); G. Allport, ThE NATURE OF PREJUdice 142-60 (1954). Cf. Hafner, Psychological Disturbances Following Prolonged Persecution, 3 Soc. PsychIATRY 79 (1968) (discussing psychological symptoms including headaches, dizziness, social withdrawal, chronic depression and anxiety neurosis in survivors of extreme persecution); Denis, Race Harassment Discrimination: A Problem That Won't Go Away?. 10 Employment Rel. L.J. 415, 432-35 (1984) (discussing damages for psychic injury in race harassment cases).

117. L. TR1BE, supra note 43, $\S 12-12$, at 861 . See Chaplinsky v. New Hampshire, 315 U.S. 568 (1942) (classifying libel as wholly outside the scope of first amendment protection); Beauharnais v. Illinois, 343 U.S. 250 (1952) (including group defamation among unprotected libelous statements).

118. 376 U.S. 254,270 . 
possibility of libel suits-these cases also demonstrate a concern for balancing the public's interest in being fully informed with the competing interest of defamed persons in vindicating their reputation. ${ }^{119}$

Brown is a case about group defamation. The message of segregation was stigmatizing to black children. To be labeled unfit to attend school with white children imjured the reputation of black children, thereby foreclosing employment opportunities and the right to be regarded as respected members of the body politic. An extensive discussion on the constitutionality or efficacy of group libel laws is beyond the

119. Implicit in the Sullivan rule is the proposition that the first amendment establishes a right to speak defamatory truth. The Sullivan case,

prohibits a public official from recovering damages for a defamatory falsehood relating to his or her official conduct unless he or she proves that the statement was made with "actual malice"-that is, with knowledge that it was false or reckless disregard of whether it was false or not.

Id. at 279-80. This privilege for good faith critics of government officials was created in order to protect against the self-censorship of the speaker who fears that he has guessed wrong in his effort to speak the truth. Lawrence Tribe notes that, "A rule that the first amendment protects the right to utter the truth clearly does not suffice, because 'erroneous statement is inevitable in free debate,' and the only guarantec of legal safety under such a rule is silence." See L. TR1BE, supra note $43, \S 12-12$, at 864 (quoting Sullivan, 376 U.S. at 271-72).

But the self-censorship rational of Sullivan is inapplicable in cases involving speech which, rather than critiquing those in power, asserts the inferiority of an entire racially subordinated group. Sullivan is primarily a case about the unconstitutionality of labeling speech as seditious libel. It is concerned with censorship of criticism of government. The defamation of blacks or other racial minorities, as groups, does not involve criticism of government. Even when a racial epithet is used to attack a public official, the alleged inferiority of the racial group to which he belongs should not be held to be related to his fitness to hold the position. The individual who defames a racial group with racial epithets and stereotyped earicatures is not concerned that he may have "guessed wrong" in attempting to ascertain the truth. The racial epithet is the expression of a widely held belief. It is invoked as a statement of political belief-not as a statement of fact which may be proven true or erroneous. Moreover, if the Sullivan rule protects erroneous speech because of an ultimate concern for the discovery of truth, then the rule's application to racial epithets must be based on an acceptance of the possible "truth" of racism, a position which, happily, most first amendment absolutists are reluctant to embrace. Professor Matsuda argues that "we [should] accept certain principles as the shared historieal legacy of the world community. Racial supremacy is one of the ideas we have collectively and internationally considered and rejected." See Matsuda, supra note 25, at 2360.

But Sullivan also held that "the central meaning of the first amendment is the profound national commitment to the principle that debate on public issues should be uninhibited, robust and wide open." 376 U.S. at 270 . Some civil libertarians argue that the status and attributes of various racial groups are public issues about which vigorous debate should be encouraged. See Strossen, supra note *, at 560 (arguing that if "ugly" racist speech is chilled by university sanctions there will be less discussion about the underlying problems of racism). This proposition is combined with the proposition that there is no such thing as a false idea to argue that Sullivan has necessarily overruled Beauharnais v. Illinois, 343 U.S. 250 (1952). But are racial insults ideas? Do they encourage wideopen debate?

The solution might lie in establishing the equivalent of an actual malice requirement. Discussions that attempt to explore an issue of public concern would be protected, but group defamations that intentionally vilify a group or individual for purposes of harassment or intimidation would receive no protection. 
scope of this essay. ${ }^{120}$ However, it will suffice to note that whereas Beauharnais v. Illinois, ${ }^{121}$ which upheld an Illinois group libel statute, has fallen into ill repute; ${ }^{122}$ and is generally considered to have been overruled imphicitly by Sullivan, Brown remains an instructive case. By identifying the inseparability of discriminatory speech and action in the case of segregation, where the injury is inflicted by the meaning of the message, Brown limits the scope of Sullivan. ${ }^{123}$ Brown reflects that racism is a form of subordination that achieves its purposes through group defamation. ${ }^{124}$

The third mjury identified in Brown is the denial of equal educational opportunity. Brown recognized that black children did not have an equal opportunity to learn and participate in the school community if they bore the additional burden of being subjected to the humiliation and

120. There are compelling arguments to be made for the continuing viability and correctness of Beauharmais. See Arkes, Civility and the Restriction of Speech: Rediscovering the Defamation of Groups, 1974 SUP. CT. REV. 281, 292 (One who rejects the notion of group libel must also reject that "certain minority groups in this country have in fact suffered injuries in the past as a result of racist stereotypes that have been perpetuated in the public mind."); see also Downs, Skokie Revisited: Hate Group Speech and the First Amendment, 60 NoTRE DAME L. REv. 629, 661-66 (1985) (statutes similar to the one in Beauharnais unconstitutional unless the speech in question is racial vilification targeted at an individual or discrete group).

121. 343 U.S. 250 (1952).

122. See L. TRIBE, supra note 43, § 12-17, at 926-27. See also Collin v. Smith, 578 F.2d 1197 , 1205 (7th Cir. 1978) (questioning whether Beauharnais remains good law in the wake of the constitutional libel cases), cert. denied, 439 U.S. 916 (1978).

123. See supra notes 114-19 and accompanying text. The Court has recognized the inseparability of discriminatory speech and conduct in sustaining the regulation of sexist (and presumably racist) speech in Pittsburgh Press Co. v. Human Relations Commission, 413 U.S. 376 (1973), where the Court held that sex-designated "help wanted" advertising columns could be prohibited since such ads "aided" unlawful sex discrimination in hiring. Id. at 389, 394. Similarly, regulation of "racist" advertising for home sales and rentals has been upheld against free speech claims.

124. For a discussion of the anti-discrimination principle of the equal protection clause and the centrality to that principle of the injury due to group defamation, see Lawrence, supra note 20 , at 350-51. He observes that:

The prevention of stigma was at the core of the Supreme Court's unanimous declaration in

Brown v. Board of Education that segregated public schools are inherently unequal. . . .

The social meaning of racial segregation in the United States is the designation of a superior and an inferior caste, and segregation proceeds "on the ground that colored citizens are ... . inferior and degraded."

Stigmatizing actions harm the individual in two ways: They inflict psychological injury by assaulting a person's self-respect and human dignity, and they brand the individual with a sigu that signals her inferior status to others and designates her as an outcast. Id. (footnotes omitted). See also Fiss, Groups and the Equal Protection Clause, 5 PHIL. \& PUB. AFF. $107,108,129-70$ (1976) (Common anti-discrimination doctrine is unduly limited to individualistic concerns, and to an assessment of the means as opposed to the ends of discrimination. A group disadvantaging principle would capture the equality ideal more completely). 
psychic assault that accompanies the message of segregation. ${ }^{125}$ University students bear an analogous burden when they are forced to live and work in an environment where, at any moment, they may be subjected to denigrating verbal harassment and assault. The testimony of non-white students about the detrimental effect of racial harassment on their academic performance and social integration in the college community is overwhelming. ${ }^{126}$ A similar injury is recognized and addressed in Title VII's requirement that employers maintain a nondiscriminatory (non-

125. In explaining why segregated educational facilities were inherently unequal, the Brown Court said, "To separate [Negro children] from others of similar age and qualifications solely because of their race generates a feeling of inferiority as to their status in the community that may affect their hearts and minds in a way unlikely ever to be undone." 347 U.S. 483, 494. The Court went on to quote the federal district court in Kansas which had found that "[a] sense of inferiority [engendered by segregated schools] ... has a tendency to [retard] the educational and mental development of Negro children." Id.

126. Report of President's Ad Hoc Committee on Racial Harassment, University of Texas at Austin, Nov. 27, 1989 (university president urged to initiate an investigation into the problem of racial harassment on the campus). The committee instituted hearings receiving both written and verbal testimony.

[M]any speakers felt that they had experienced racism, resulting in deep feelings of personal anger, distress and isolation in the academic community. Such experiences produce alienation from, rather than a supportive relationship with, The University. They also were concerned that there was no specific place to seck redress at The University for complaints of racial harassment.

Id. at 2; MASSACHUSETTS COMMISSION AGAINST DISCRIMINATION, REPORT OF UNIVERSITY OF MASSACHUSETTS INVESTIGATION 2 (1986) (investigation of 1986 racial incident on campus cited need to "review . . . the context of recent UMASS [racial] history," to better understand the factors that led to what most witnessing the incident characterized as a "race riot").

Note that many of these incidents go unrecorded because universities have not taken a stand against racist speech, defining it as a reportable offense or provided meehanisms or forums for reporting these incidents and their effeet. A similar situation exists with regard to sexual harassment. See Sexual Harassment Survey, Student Affairs Research \& Evaluation Office, University of Massachusetts at Amherst (S89-C Feb. 1989). The University of Massachusetts study was designed to assess the feelings of students about sexual harassment and the mechanisms at the University to address their concerns. Although a majority of the students surveyed expressed first- or secondhand experience with sexual harassment, $34.2 \%$ of the women were unaware that there was a university policy prohibiting the harassment, and $60 \%$ were unaware of the university's specific grievance procedure. See also Kent, The Silence of Survivors: Reporting Rape-Hazy Definition and Lack of Protocol Impede Reporting, Stanford Daily, Feb. 28, 1990, at 1, col. 2 ("[M]any people decide not to report aequaintance rape, and those who work with the issue say a main reason is that the University has no formal protocol for reporting highly sensitive cases like rape."). 
hostile) work environment ${ }^{127}$ and in federal and state regulations prohibiting sexual harassment on campuses as well as in the work place. ${ }^{128}$

All three of these very tangible, continuing, and often irreparable forms of injury-psychic, reputational, and the denial of equal educational opportunity-nust be recognized, accounted for, and balanced against the claim that a regulation aimed at the prevention of these injuries inay lead to restrictions on iniportant first amendment liberties.

\section{B. The Other Side of the Balance: Does the Suppression of Racial Epithets Weigh for or Against Speech?}

In striking a balance, we also nuust think about what we are weighing on the side of speech. Most blacks-unlike niany white civil libertarians-do not have faith in free speech as the most important vehicle for liberation. The first aniendinent coexisted with slavery, and we still are not sure it will protect us to the saine extent that it protects whites. It often is argued that ninorities have benefited greatly froin first amendment protection and therefore should guard it jealously. We are aware that the struggle for racial equality has relied heavily on the persuasion of peaceful protest protected by the first ainendment, but experience also teaches us that our petitions often go unanswered until they disrupt business as usual and require the self-interested attention of those persons in power. ${ }^{129}$

127. For example, in Meritor Savings Bank v. Vinson, 477 U.S. 57 (1986), the Supreme Court held that sexual harassment that creates a hostile or abusive work environment constitutes a violation of 'Title VII's prohibition against sex discrimination in employment. The Court referred to an EEOC guideline that defined sexual harassment as "[u]nwelcome sexual advances, requests for sexual favors and other verbal and physical conduct of a sexual nature." Id. at 65 . The Court also made clear that racial harassment would violate Titlc VII. Although thc Court has noted that "mere utterance of an ethnic or racial epithet which engenders offensive feelings in an employee" is not by itself actionable conduct under the statute, this is not because the racial epithet is protected by the first amendment, but because the legislature has not detcrmined that, standing in isolation, it is an act of employment discrimination. Id. at 67 (citing Rogers v. EEOC, 454 F.2d 234 (5th Cir. 1971), cert. denied, 406 U.S. 957 (1972)).

128. See Alexander v. Yale University, 631 F.2d 178, 184 (1980) ("In a Title $1 \mathrm{X}$ suit, it is the deprivation of 'educational' benefits which, once proven, allows the court to afford relief. The statute recognizes that loss of edueational benefits is a significant injury, redressable by law." However, the court ruled that the damages were too speculative to receive judicial remedy.).

129. Professor Derrick Bell has argued that the civil rights demonstrations of the 1960 s were effective to the extent that they were successful in fomenting "creative disorder." He notes that these protests were all disruptive in one way or another in that they disturbed the peace and tranquility of the status quo, posed a threat of civil disorder, and challenged closely-held beliefs. Often, as with the sit-ins and boycotts, they threatened economic loss and political problems. Indeed, most of these protests resulted in violence, although the violence was most often perpetrated against the protestors. See D. BELL, supra note 50, at 283-87, 287-330. 
Paradoxically, the disruption that renders this speech effective usually causes it to be considered undeserving of first amendment protection. 130 Note the cruel irony in the news story appearing in the "Newsreel" at the beginning of this Article that describes Stanford President Kennedy's justification for prosecuting students engaged in a peaceful sit-in for violation of the University's Fundamental Standard. While protesting students were punished, the racist behavior the students were protesting went unpunished. This lack of symmetry was justified on the grounds that punishment might violate the bigots' first amendment rights. ${ }^{131}$ Once faith in this symmetry is shaken, the absolutist position loses credence. It is difficult for us to believe that we should fight to protect speech rights for racists because that will ensure our own speech rights. Our experience is that the American system of justice has never been symmetrical where race is concerned. No wonder we see equality as a precondition to free speech, and we place more weight on that side of the balance aimed at the removal of the badges and incidents of slavery that continue to flourish in our culture.

Blacks and other people of color are equally skeptical about the absolutist argument that even the most injurious speech must remain unregulated because in an unregulated marketplace of ideas the best ideas will rise to the top and gain acceptance. ${ }^{132}$ Our experience tells us the

130. In examining the first amendment cases coming out of the civil rights protests of the 1960 s one observes that although the Court went to some length to reverse convictions in peaceful protests designed to achieve conformity with Brown, they generally denied review to those cases in which there was evidence of disruption or violence-particularly in those cases where the disruption seemed to emanate from the protestors. Compare Brown v. Louisiana, 383 U.S. 131, 151 (1966) (Black, J., dissenting) (reversing the disorderly conduct conviction of blacks who participated in a non-violent and ostensibly quiet sit-in at a public library that barred blacks) with Walker v. City of Birmingham, 388 U.S. 307 (1967) (upholding contempt convictions for violating an injunction against the Good Friday and Easter Sunday Birmingham marches, noting the critical importance of law and order) and Cameron v. Johnson, 390 U.S. 611, 617 (1968) (ruling that picketers at voting registration facilities could be arrested for violating Mississippi law that prohibits conduct which "unreasonably interferes with ingress or egress to or from a courthouse"). See also D. BELL, supra note 50, at 296-300 (noting that as the "non-violent, prayer-oriented Southeru protests of the early 1960s" grew in militancy, the Court continued its earlier practice of ruling against the protesters when the protest was accompanied by violence).

131. Derrick Bell notes an additional irony in observing that it was black students' civil rights protests that established the precedents upon which white students relied to establish their first amendment rights in school and university settings. See Tinker v. Des Moines Indep. Cominunity School Dist., 39 U.S. 503 (1969) (relying upon Dixon v. Alabama Bd. of Educ., 294 F.2d 150 (5th Cir. 1961)). Bell asserts that when "policy changes are effected, whites usually will prove the primary beneficiaries, and blacks will have paid the inajor cost." D. BeLL, supra note 50, at 457.

132. The "marketplace of ideas" model sees speech as instrumental to democratic self government. It argues that truth (or the best perspectives or solutions) can be discovered through robust debate, frec from government interference. In this model, the value of free speech lies not in the liberty interests of individual speakers, but in the societal benefits derived from unimpeded discussion. This theory has its origins in JoHN STUART MILL's, ON LIBERTY ch. 2 (1859) (S. Collini ed. 
opposite. We have seen too many demagogues elected by appealing to America's racism. We have seen too many good, liberal politicians shy away from the issues that might brand them as too closely allied with us. The American marketplace of ideas was founded with the idea of the racial inferiority of non-whites as one of its chief commodities, and ever since the market opened, racism has remained its most active item in trade. ${ }^{133}$

But it is not just the prevalence and strength of the idea of racism that makes the unregulated marketplace of ideas an untenable paradigm for those individuals who seek full and equal personhood for all. The real problem is that the idea of the racial inferiority of non-whites infects, skews, and disables the operation of the market (like a computer virus, sick cattle, or diseased wheat). Racism is irrational and often unconscious. ${ }^{134}$ Our belief in the inferiority of non-whites trumps good ideas that contend with it in the market, often without our even knowing it. ${ }^{135}$ In addition, racism makes the words and ideas of blacks and other despised minorities less saleable, regardless of their intrinsic value, in the marketplace of ideas. ${ }^{136}$ It also decreases the total amount of speech that enters the market by coercively silencing members of those groups who are its targets. ${ }^{137}$

Racism is an epidemic infecting the marketplace of ideas and rendering it dysfunctional. Racism is ubiquitous. We are all racists. ${ }^{138} \mathrm{Ra}$ cism is also irrational. Individuals do not embrace or reject racist beliefs

1989). Justice Holmes established its place in first amendment jurisprudence in his dissent in Abrams v. United States, 250 U.S. 616 (1919):

But when men have realized that time has upset many fighting faiths, they may come to believe... that the best test of truth is the power of the thought to get itself accepted in the competition of the market, and that truth is the only ground upon which their wishes can safely be carried out.

Id. at 630 .

133. See Lawrence, supra note 20, at 330 ("[Racism] is a part of our common historical experience and, therefore, a part of our culture .... We attach significance to race even when wc are not aware that we are doing so ... . Racism's universality renders it normal.").

134. Id. at 339-44; see infra notes $139-40$ and accompanying text.

135. See Lawrence, supra note 20, at $341 \mathrm{n} .101$ (relating the story of a Mexican-American law student who was complimented by a middle-aged white male interviewer: "You speak very good English." The student responded that her family has lived in Santa Barbara for four generations. The interviewer was unconscious of the racial stereotype underlying his intended compliment.).

136. Catharine MacKinnon argues, similarly, that pornography causes women to be taken less seriously as they enter the public arena. MacKinnon, supra note 47, at 325-26, 335 (1984). See also Sunstein, Pornography and the First Amendment, 1986 DUKE L.J. 589, 618-19 (analogizing the case for anti-pornography legislation to footnote four in United States v. Carolene Products, 304 U.S. 144,152 (1938), and rccognizing "maldistribution of private power").

137. See supra notes 88-92 and accompanying text.

138. See Lawrence, supra note 20, where he describes America's racist heritage:

Americans share a common historical and cultural heritage in which racism has played and still plays a dominant role. Because of this shared experience, we also inevitably share 
as the result of reasoned deliberation. ${ }^{139}$ For the most part, we do not recognize the myriad ways in which the racism pervading our history and culture influences our beliefs. In other words, most of our racism is unconscious. ${ }^{140}$

The disruptive and disabling effect on the market of an idea that is ubiquitous and irrational, but seldom seen or acknowledged, should be apparent. If the community is considering competing ideas about providing food for children, shelter for the homeless, or abortions for pregnant women, and the choices made among the proposed solutions are influenced by the idea that some children, families, or women are less deserving of our sympathy because they are not white, then the market is not functioning as either John Stuart Mill or Oliver Wendell Holmes envisioned it. In John Ely's terms there is a "process defect."141

Professor Ely coined the term "process defect" in the context of developing a theory to identify instances in which legislative action should be subjected to heightened judicial scrutiny under the equal protection

many ideas, attitudes, and beliefs that attach significance to an individual's race and induce negative feelings and opinions about non-whites. To the extent that this cultural belief system has infiuenced all of us, we are all racists.

Id. at 322 .

139. For a more detailed discussion of the irrationality of racism, see Lawrence, supra note 20, at 331-36 (discussing the persistence of racist thinking despite personal experience that contradicts the racist belief; racist beliefs based on instinctive and unexplained distaste for members of the target group). Marie Jahoda notes that "racial prejudice, in its narrowest sense, is an attitude towards outgroups which refrains from reality-testing not just because the mental effort is too much but because the attitude itself fulfills a specific irrational function for its bearer." M. JAHODA, RACE RELATIONS AND MeNTAL Health 11 (1960) (UNESCO publication). See also G. AlLPORT, supra note 116, at 85-87, 317-19.

140. I have explored the phenomena of unconscious racism and its relationship to the jurisprudence of equal protection at some length elsewhere. See Lawrence, supra note 20. In that article I noted two explanations for the predominance of unconscious racist beliefs and ideas:

First, Freudian theory states that the human mind defends itself against the discomfort of guilt by denying or refusing to recognize those ideas, wishes, and beliefs that conflict with what the individual has learned is good or right. While our historical experience has made racism an integral part of our culture, our society has more recently embraced an ideal that rejects racism as immoral. When an individual experiences confict between racist ideas and the societal ethic that condemns those ideas, the mind excludes his racism from consciousness.

Second, the theory of cognitive psychology states that the culture-including, for example, the media and an individual's parents, peers, and authority figures-transmits certain beliefs and preferences. Because these beliefs are so much a part of the culture, they are not experienced as explicit lessons. Instead, they seem part of the individual's rational ordering of her perceptions of the world. The individual is unaware, for example, that the ubiquitous presence of a cultural stereotype has influenced her perception that blacks are lazy or unintelligent. Because racism is so decply ingrained in our culture, it is likely to be transmitted by tacit understandings: Even if a child is not told that blacks are inferior, he learns that lesson by observing the behavior of others. These tacit understandings, because they have never been articulated, are less likely to be experienced at a conscious level.

Id. at 322-23 (footnotes omitted).

141. See J. Ely, Democracy and Distrust: A Theory of Judicial Review 103-04, 13579 (1980). 
clause. Ely argues that the courts should interfere with the normal majoritarian political process when the defect of prejudice bars groups subject to widespread vilification from participation in the political process and causes governmental decisionmakers to misapprehend the costs and benefits of their actions. ${ }^{142}$ This same process defect that excludes vilified groups and misdirects the government operates in the marketplace of ideas. Mill's vision of truth emerging through competition in the marketplace of ideas relies on the ability of members of the body politic to recognize "truth" as serving their interest and to act on that recognition. ${ }^{143}$ As such, this vision depends upon the same process that James Madison referred to when he described his vision of a democracy in which the numerous minorities within our society would form coalitions to create majorities with overlapping interests through pluralist wheeling and dealing. ${ }^{144}$ Just as the defect of prejudice blinds the white voter to interests that overlap with those of vilified minorities, it also blinds him to the "truth" of an idea or the efficacy of solutions associated with that vilified group. ${ }^{145}$ And just as prejudice causes the governmental decisionmakers to misapprehend the costs and benefits of their actions, it also causes all of us to misapprehend the value of ideas in the market.

Prejudice that is unconscious or unacknowledged causes even more distortions in the market. When racism operates at a conscious level, opposing ideas may prevail in open competition for the rational or moral sensibilities of the market participant. But when an individual is unaware of his prejudice, neither reason nor moral persuasion will likely succeed. ${ }^{146}$

Racist speech also distorts the marketplace of ideas by muting or devaluing the speech of blacks and other non-whites. An idea that would be embraced by large numbers of individuals if it were offered by a white individual will be rejected or given less credence because its author belongs to a group demeaned and stigmatized by racist beliefs.

142. Id. at 152-58.

143. J.S. MILL, supra note 132, at ch. 2.

144. The Federalist No. 51, at 323-24 (J. Madison) (C. Rossiter ed. 1961).

145. J. Ely, supra note 141, at 153.

146. See Lawrence, supra note 20, at $347-49$ (arguing that Ely's process defect theory is incomplete to the extent that it does not take into account the process distortions caused by unconscious racism). 
An obvious example of this type of devaluation would be the black political candidate whose ideas go unheard or are rejected by white voters, although voters would embrace the same ideas if they were championed by a white candidate. ${ }^{147}$ Racial minorities have the same experiences on a daily basis when they endure the microaggression of having their words doubted, or misinterpreted, or assumed to be without evidentiary support, ${ }^{148}$ or when their insights are ignored and then appropriated by whites who are assumed to have been the original authority. ${ }^{149}$

Finally, racist speech decreases the total amount of speech that reaches the market. I noted earlier in this Article the ways in which racist specch is inextricably linked with racist conduct. The primary purpose and effect of the speech/conduct that constitutes white suprenacy is the exclusion of non-whites froin full participation in the body politic. Solnetimes the speech/conduct of racism is direct and obvious. When the Klan burns a cross on the lawn of a black person who joined the NAACP or exercised his right to move to a formerly all-white

147. Exit polls taken during the recent mayoral election in New York City and the gubernatorial election in Virginia overstated the support among white voters for the black candidates. The discrepancy has been attributed to a reluctance among white voters to admit, even anonymously, to not voting for a black candidate. Rosenthal, Broad Disparities in Votes and Polls Raising Questions, N.Y. Times, Nov. 9, 1989, at A1, col. 2.

Once again, the experience of one of my gay students provides the paradigmatic example of how ideas are less acceptable when their authors are members of a group that has been victimized by hatred and villification. Bob had not "come out" when he first came to law school. During his first year, when issues relating to heterosexism came up in class or in discussions with other students, he spoke to these issues as a sympathetic "straight" white male student. His arguments were listened to and taken seriously. In his second year, when he had "come out" and his classmates knew that he was gay, he found that he was not nearly as persuasive an advocate for his position as when he was identified as "straight." He was the same person saying the same things, but his identity gave him less authority.

148. See Davis, Law as Microaggression, 98 YALE L.J. 1559, 1568 (1989) (describing a courthouse scene in which a white city attorney seizes upon the most pejorative interpretation of a black woman's question: "The inferiority of the black is more than an implicit assertion; it is a background assumption that supports the seizure of a prerogative.").

149. See G. Lopez, The Well-Defined Academic Identity (Jan. 7, 1990) (unpublished manuscript) (available from author) (AALS Law and Humanities panel speech on white revisionism of scholars of color); Delgado, The Imperial Scholar: Refiections on a Review of Civil Rights Literature, 132 U. PA. L. REV. 561, 564-65 (1984); Weiss \& Melling, The Legal Education of Twenty Women, 40 STAN. L. REv. 1299, 1336 (1988) ("There were times when women made points, and they were ignored or trivialized. Five minutes later, a man would make the same point . . . and it was discussed."); Fox, Women and Higher Education: Sex Differentials in the Status of Students and Schol$a r s$, in Women: A Feminist Perspective 238, $244-46$ (J. Frecman 3d ed. 1989) (a "subtle and silent language differentiates males and females"; faculty encourages males while "reinforce[ing] the invisibility of female students"); G. STEINEM, Men and Women Talking, in Outrageous Acts AND EVERYDAY REBELLIONS 176 (1983) (gender differences in communication often due to sexism, not biology-to transform "politics of talking" requires a feminist assault). 
neighborhood, the effect of this speech does not result from the persuasive power of an idea operating freely in the market. It is a threat, a threat made in the context of a history of lynchings, beatings, and economic reprisals that made good on earlier threats, a threat that silences a potential speaker. ${ }^{150}$ The black student who is subjected to racial epithets is likewise threatened and silenced. Certainly she, like the victim of a cross-burning, may be uncommonly brave or foolhardy and ignore the system of violence in which this abusive speech is only a bit player. But it is more likely that we, as a community, will be denied the benefit of many of her thoughts and ideas. ${ }^{151}$

Again MacKinnon's analysis of how first amendment law misconstrues pornography is instructive. She notes that in concerning themselves only with government censorship, first amendment absolutists fail to recognize that whole segments of the population are systematically silenced by powerful private actors. "As a result, [they] cannot grasp that the speech of some silences the speech of others in a way that is not simply a matter of competition for airtime."152

\section{Asking Victim Groups to Pay the Price}

Whenever we decide that racist hate speech must be tolerated because of the importance of tolerating unpopular speech we ask blacks and other subordinated groups to bear a burden for the good of societyto pay the price for the societal benefit of creating more room for speech. And we assign this burden to them without seeking their advice, or consent. This amounts to white domination, pure and simple. ${ }^{153}$ It is taxation without representation. We must be careful that the ease with which we strike the balance agamst the regnlation of racist speech is in no way influenced by the fact the cost will be borue by others. ${ }^{154}$ We must be

150. When speech directly threatens violence, as in the phrase "your money or your life" or in the phone call that takes responsibility for the terrorist bomb attack and threatens another, we recognize its inextricability from the accompanying conduct. It is more difficult to rccognize the threat when the violence is systemic and need not be directly referenced in the speech, but the threat is just as effective, arguably even more so.

151. Catharine MacKinnon has noted that it is difficult to demonstrate empirically that pornography chills women's speech because "silence is not eloquent." C. MACKINNON, supra note 53, at 206.

152. Id.

153. See R. Dworkin, LAw's EMPIRE 286-92 (1986) (increasing the social wealth of the community along purely utilitarian lines may undercut critical moral convictions).

154. Mari Matsuda has explored the ways that racist speech destroys normal relations and normal social interaction between groups. Among these is the way in which whites eannot help but feel a moment of relief that they are not the target, even as they reject the message of hate-speech.

I know, for instance, that when I get anti-Semitic literature, two things go on: one, anger, and two, a moment when 1 think, it's not me, thank God. Then $I$ have to reject that and 
certain that the individuals who pay the price are fairly represented in our deliberation, and that they are heard.

Even as our discussions concerning the efficacy of regulating racist speech on campuses continue, they evidence our lack of attention to the costs of constitutional injury borne by the victims. I have had scores of conversations about this topic over the past several months with students, colleagues, university administrators, ACLU board members, reporters, friends, relatives, and strangers. By now there is an experience of déjà $v u$ each time I am asked to explain how a good civil libertarian like myself - a veteran of 1960 s sit-ins and demonstrations, a liberal constitutional law professor, and a person who has inade antiestablishment speech his vocation-could advocate censorship. I try to be patient, articulate, and good-natured as I set forth the concerns and arguments explored in this Article. I try to listen carefully, to remain open to others' experiences and to my own strong instincts against governmental incursion on individual liberty.

Often when I am at my best, even the most steadfast defenders of the first amendment faith will concede that these are persuasive arguments. They say they agree with much of what I have said, they recognize I am proposing narrowly framed restrictions on only the most abusive, least substantive forms of racist speech, and they understand the importance of hearing the victims' stories. Then they say, "But I'm afraid I still come out differently froin you in the end. I still don't see how we can allow even this limited regulation of racist speech without running soine risk of endangering our first annendment liberties."

One of these encounters occurred at a recent dinner with colleagues in New York. My good friend and former colleague john powell-john is National Legal Director of the ACLU and he is black-was in attendance. He told the following story:

My family was having Thanksgiving dinner at the home of friends.

-We are vegetarians and my two kids were trying to figure out which of the two dressings on the table was the vegetarian dressing and which was the meat dressing. One of our hosts pointed to one of the dressings and said, "This is the regular dressing and the other is the vegetarian dressing." I corrected him saying, "There is no such thing as 'regular' dressing. There is meat dressing and there is vegetarian dressing, but neither one of them is regular dressing."

say no. An attack on any people ... is an attack on me. But there is that secret guilty moment of gratitude that one is not the victim.

Language as Violence v. Freedom of Expression: Canadian and American Perspectives on Group Defamation, 37 Buffalo L. Rev. 337, 360-61 (1989) (comments of Mari Matsuda). 
This incident reminded john of the discussions he has had with his colleagues on the subject of regulating racist speech. "Somehow," he said,

I always come away from these discussions feeling that my white colleagues think about the first amendment the way my friend thought about "regular" [meat] dressing, as an amendment for regular people or all people, and that they think of the equal protection clause of the fourteenth amendment the way my friend thought about vegetarian dressing, as a special amendment for a minority of different people.

Inevitably, in these conversations, those of us who are non-white bear the burden of justification, of justifying our concern for protection under our "special" amendment. It is not enough that we have demonstrated tangible and contimuing injury committed against the victions of racist speech. There can be no public remedy for our special fourteenth amendment injury until we have satisfied our interlocutors that there is no possible risk of encroachment on their first anendment-the "regular" amendınent. ${ }^{155}$

If one asks why we always begin by asking whether we can afford to fight racism rather than asking whether we can afford not to, or if one asks why my colleagues who oppose all regulation of racist speech do not feel that the burden is theirs (to justify a reading of the first amendinent that requires sacrificing rights guaranteed under the equal protection clause), then one sees an example of how unconscious racism operates in the marketplace of ideas.

Well-meaning individuals who are committed to equality without regard to race, and who have demonstrated that commitinent in many arenas, do not recoguize where the burden of persuasion has been placed in this discussion. When they do, they do not understand why. Even as I experienced the frustration of always bearing the burden of persuasion, I did not see the source of my frustration or understand its significance until john told his story about the Thanksgiving dressing. Unfortunately, our unconscious racism causes us (even those of us who are the direct

155. Professor Strossen's response to this article, see supra note *, is paradigmatic of this approach to the issue. Throughout she acknowledges the presence of tangible and continuing injuries to non-white students from incidents of verbal racial harassment on university campuses, but, having done so, she rejects even narrowly drafted university regulations aimed at protecting those students from injury on the grounds that these regulations may chill protected speech or lead down a slippery slope to broader regulations. See id. at 541. It should be noted that, despite Professor Strossen's observation that our positions are not that far apart, she has not yet found a regulation of racially harassing speech that she will endorse nor has she drafted one hcrself. The burden, therefore, reInains with those whose rights to equal access are daily compromised to find a way to protect themselves without compromising the first amendment. 
victims of racism), to view the first amendment as the "regular" amendment-an amendment that works for all people-and the equal protection clause and racial equality as a special-interest amendment important to groups that are less valued. 156

Derrick Bell has noted that often in our constitutional history the rights of blacks have been sacrificed because sacrifice was beheved necessary to preserve the greater interests of the whole. ${ }^{157}$ It is not just the actual sacrifice that is racist but also the way the "whole with the greater interests" gets defined. Today in a world committed to the ideal of equality, we rarely notice the sacrifice or how we have avoided noticing the sacrifice by defining the interests of whites as the whole, "the regular." When we think this way, when we see the potential danger of incursions on the first amendment but do not see existing incursions on the fourteenth amendment, our perceptions have been influenced by an entire belief system that makes us less sensitive to the injury experienced by non-whites. Unaware, wc have adopted a world view that takes for granted black sacrifice.

Professor Richard Delgado has suggested there is another way in which those of us who abhor racist speech but insist that it cannot be regulated may be, perhaps unwittingly, benefiting from the presence of " $a$ certain amount of low grade racism" in the environment:

I believe that racist speech benefits powerful white-dominated institutions. The highly educated, refined persons who operate the University of Wisconsin, other universities, major corporations, would never, ever themselves utter a racial slur. That is the last thing they would do.

Yet, they benefit, and on a subconscious level they know they benefit, from a certain amount of low-grade racism in the environment. If an occasional bigot or redneck calls one of us a nigger or spick one night late as we're on our way home from the library, that is all to the good. Please understand that I am not talking about the very heavy stuff-violence, beatings, bones in the nose. That brings out the TV cameras and the press and gives the university a black eye. I mean the daily, low-grade largely invisible stuff, the hassling, cruel remarks, and other things that would be covered by rules. This kind of behavior

156. I am indebted to my friend and colleague john powell for this insight.

157. See D. BELL, supra note 50, at 30 ("In the resolution of racial issues in America, black interests are often sacrificed so that identifiably different groups of whites may settle a dispute and establish or reestablish their relationship."); D. BELL, The Real Status of Blacks Today: The Chronical of Constitutional Contradiction, in AND WE ARE Not SAvED: THE Elusive QUEST FOR RACIAL JUSTICE 26, 40 (1987) (Bell's primary protagonist, Geneva Crenshaw, addresses the delegates to the Constitutional Convention of 1787: "So . . . you are saying that slavery for blacks not only provided wealth for rich whites but, paradoxically, led also to grcater freedom for poor whites," this freedom allowed poor whites to provide more support for the struggle against the British.). 
keeps non-white people on edge, a little off balance. We get these occasional reininders that we are different, and not really wanted. It prevents us from digging in too strongly, starting to think we could really belong here. It makes us a little introspective, a little unsure of ourselves; at the right low-grade level it prevents us from organizing on behalf of more important things. It assures that those of us of real spirit, real pride, just plain leave-all of which is quite a substantial benefit for the institution. ${ }^{158}$

\section{IV. "Which Side ARe (WE) ON?"}

However one comes out on the question of whether racist hate speech should be artificially distimguished from other fighting words and given first amendment protection, it is important to examine and take responsibility for the effects of how one participates in the debate. It is important to consider how our voice is heard. We must ask ourselves whether, in our well-placed passion for preserving our first amendment freedoms, we have been forceful enough in our personal condeinnation of ideas we abhor, whether we have neglected our alliances with victims of the oppressive manifestations of the continuing dominance of these ideas within our commumities and within ourselves.

At the core of the argument that we should resist all government regulation of speech is the ideal that the best cure for bad speech is good speech, and ideas that affirm equality and the worth of all individuals ultimately will prevail over racism, sexism, homophobia, and anti-semitisin because they are better ideas. ${ }^{159}$ This is an empty ideal-one that imvites those injured or appalled by hate-speech to call for restrictions on speech - unless those of us who fight racism are vigilant and unequivocal in that fight.

There is inuch about the way many civil libertarians have participated in the debate over the regulation of racist speech that causes the victims of that speech to wonder which side they are on. Those who

158. Address by Richard Delgado, State Historical Society, Madison, Wisconsin (Apr. 24, 1989). Professor Delgado draws an analogy to Susan Brownmiller's observation that rape is the crime of all men against all women. Men who would never commit rape and who abhor it nonetheless benefit from the climate of terror that the experience of rape helps creatc.

The possibility of rape makes women defensive and scared. Some feel better at night if a man is at their shoulder. There also is an historical analogue in the black house servant who was protected from groups like the Klan as long as he had the protection of the influential whites for whom he worked. The climate in which non-whites have reason to fear for their safety continues to this day. For example, black, latino, and Asian professors in university towns often go jogging carrying university identification cards in case they are stopped by the local constabulary.

159. Despite an optimism regarding the human capacity for good that can only be cxplained by faith, I am skeptical of ideals that provide the vehicle for oppressive ideology. I do not believc that truth will prevail in a rigged game or in a contest where the referees are on the payroll of the proponents of falsity. 
raise their voices in protest against public sanctions of racist speech have not organized private protests against the voices of racism. It has been people of color, women, and gays who have held vigils at offending fraternity louses, staged candleliglit marches, counter-demonstrations and distributed flyers calling upon their classmates and colleagues to express their outrage at pervasive racisin, sexism, and homopliobia in their midst and to show their solidarity with its victims.

Traditional civil hibertarians have been conspicuous largely in their absence from these group expressions of condemnation. Their failure to participate in this marketplace response to speech witl more speech is often justified, paradoxically, as concern for the principle of frec speech. When racial imnorities or other victims of hate speech hold counter-deinonstrations or engage in picketing, leafletting, heckling, or booing of racist speakers, civil libertarians often accuse them of private censorship, of seeking to silence opposing points of view. ${ }^{160}$ When both public and private responses to racist speecl are rejected by first annendment absolutists as contrary to the principle of free speech, it is no wonder that the victims of racism do not consider thein allies.

Blacks and other racial minorities also are made skeptical by the resistance encountered when we approach traditional civil liberties groups like the ACLU witl suggestions that they merely reconsider the ways they engage in this complex debate concerning speech and equality. Traditional civil liberties lawyers typically lave elected to stand by while universities have responded to the outbreak of hate speech by adopting regulations that often are drafted witl considerable attention to appeasing various, widely diverging political constituencies and only passing concern for either free speech or equality. ${ }^{161}$ Not surprisingly, these regulations are vague and overbroad. They provide easy prey for the white-

160. Increasingly, conservative white males have appropriated the rhetoric of "silencing" from the feminist and other outsider groups. See, e.g., Williams, Organizations Meet on Law School Issues, Stan. L.J., Oct. 1988, at 1, col. 4 (describing a meeting with Stanford deans and student organization represcntatives on the problem of classroom silencing). In the spring of 1987 students of color, gay and lesbian students and women students organized a panel on silence in the classroom. Panel members described the various ways in which their voices are not heard in traditional white male dominated law school classroom. Several conservative white males complained that they were not represcnted on the panel, arguing that they too were silenced by the dominant liberal culture among students and faculty. One student complained that one of his professors had referred to Chief Justice Rehnquist as Darth Vadar. (The alleged culprit was a white male professor.) One of the panel members, a lesbian, responded to the complaining student by saying, "If the Chief Justice of the Supreme Court were a radical lesbian femimist, I wouldn't care what my Con Law professor called her."

161. I believe that there is an element of unconscious collusion in the inability of universities, some with top notch legal staffs and fine law schools, to draft narrow, carefully crafted regulations. For example, it is difficult to believe that anyone at the University of Michigan Law School was consulted in drafting the regulation which was struck down at that university. See Doe v. University 
hatted defenders of the first amendment faith who dutifully march into court to have them declared unconstitutional. ${ }^{162}$

Minority delegates to the 1989 ACLU Bienırial Convention proposed a different approach. Their approach was to have the ACLU offer its expertise to schools and universities at the beginning of the legislative process, instead of waiting until the end to attack a predictably unacceptable regulation. ${ }^{163}$ In the view of minority delegates, hearings should be held on university campuses where the incidence and nature of the injury of racist speech could be carefully documented and responses that were least restrictive of protected speech could be recominended. Such an approach would serve two important purposes. It would give civil libertarians an opporturity to influence the process froin the outset, ensuring that the regulation reflected their constitutional concerns. It also would signal to racial minorities and other hate speech victims that the civil hberties cominumity is aware of and concerned about issues of equality as well as free speech. But this approach to racist speech incidents was rejected at the national convention and has faced strong opposition when proposed to regional ACLU boards. ${ }^{164}$

There is also a propensity annong some civil libertarians to minimalize the injury to the victims of racist speech and distance themselves froin it by characterizing individual acts of racial harassment as aberrations, as isolated incidents in a community that is otherwise free of racism. When

of Mich., 721 F. Supp. 852 (1989). It is almost as if the university purposefully wrote an unconstitutional regulation so that they could say to the black students, "We tried to help you but the courts just won't let us do it."

162. It is not enough that some civil liberties lawyers have waited to attack poorly drafted and obviously overbroad regulations. Those lawyers have then pointed to these same regulations' inadequacies as evidence of the danger that efforts to regulate racist speech will inevitably lead to rules that will chill expression that should be protected. See, e.g., Strossen supra note *, at 526-30 (citing several problems with the University of Michigan's clearly overbroad statute in support of her argument that the recently adopted Stanford University proposed regulation also is unconstitutional and that even narrow anti-hate-speech rules may contain constitutional pitfalls").

163. For text of adopted resolution see Strossen, supra note *, at 484 n.†. Professor Strossen cites the ACLU's policy on sexual harassment in the workplace as evidence of that organization's non-absolutist view of protected speech. See Strossen, supra note *, at 498-99. In the course of ongoing discussions regarding its policies on racist speech, some members of the ACLU have suggested that the organization adopt a policy concerning racist speech on campus that tracks its policy on sexual harassment in the workplace. Thus far, the suggestion has not found widespread support within the ranks of the organization. Initially, this suggestion did not find widespread support within the organization. Shortly after the Biennial Convention, the California chapters adopted a policy that closely followed the one suggested by minority delegates. Subsequently, a similar policy was adopted by the national organization.

164. For a history of the heated debate around ACLU policy concerning racist speech within the boards of two California regions, see Blum \& Lobaco, Fighting Words at the ACLU, CALIF. LAw., Feb. 1990, at 43. The National Legal Director of the ACLU, john powell, has begun to reopen this discussion within the ACLU at the national level. For Professor Strossen's comments on the ACLU's focus on this issue, see Strossen, supra note *, at 496-500. 
those persons who argue against the regulation of racist speech speak of "silencing a few creeps" or argue that "the harm that censors allege will result unless speech is forbidden rarely occurs," they demonstrate an unwillingness even to acknowledge the injury. Moreover, they disclaim any responsibility for its occurrence. ${ }^{165}$

The recent outbreak of racism on our campuses in its most obvious manifestations provides an opportumity to examine the presence of less overt forms of racism within our educational institutions. But the debate that has followed these imcidents has focused on the first amendment freedoms of the perpetrators rather than the university community's responsibility for creating an environment where such acts occur. The resurgence of flagrant racist acts has not occurred in a vacuum. It is evidence of more widespread resistance to change by those holding positions of dominance and privilege in institutions, which until recently were exclusively white. Those who continue to be marginalized in these institutions-by their token inclusion on faculties and administrations, by the exclusion of their cultures from core curricula, and by conimitments to diversity and multi-culturalism that seem to require assimilation more than any real change in the umiversity-cannot help but see their colleagues' attention to free speech as an avoidance of these larger issues of equality. ${ }^{166}$

165. A recent conversation with a colleague about an incident at Stanford exemplifies this phenomenon. Two white freshmen had defaced a poster bearing the likeness of Beethoven. They had colored the drawing of Beethoven brown, given it wild curly hair, big lips and red eyes and posted it on the door of a black student's dorm room in Ujamaa, the black theme house. An investigation of the incident revealed that the two white students involved had been in an argument with the same black student the night before. They had contested the black student's assertion that Beethoven was of African descent. See Two Racial Incidents Strike Ujamaa House, Stanford Daily, Oct. 17, 1988, at 1, col. 4. It appeared that the "Sambo"-like defacement of the portrait was the white students' final rebuttal to the black student's claim of familial relationship with the great composer-that this caricature was meant to ridicule the idea that such a genius could be black-could be "sambo."

My colleague shared my outrage at these students' behavior but went on to say that he thought that I had misinterpreted the import of the incident in viewing it as a manifestation of more widespread racism at Stanford. To the contrary, he was inclined to explain the students' behavior as that of two rather isolated, iguorant, misguided youth acting out against the dominant liberal culture. This hardly seemed an accurate description to me. The message conveyed by the defaced poster replicated, in a crude form, an argument that was being made by much of the Stanford faculty in the then current debate over Stanford's Western Civilization requirement. The thrust of much of the argument for maintaining a Eurocentric curriculum requirement that included no contributions of people of color was that there were no significant non-European contributions to be included. The students' defacement had added a graphic footnote to that argument. It seemed to me-contrary to my colleague's explanation of the students' behavior-that they were imitating their role models in the professoriate, not rebelling against them.

166. Some civil libertarians have argued that regulating a limited eategory of racist fighting words will only make a marginal difference in the atmosphere for blacks on eampus. They urge that the larger problems of racist attitudes and institutional practices will remain and that our resources are better spent on combating those problems. See Strossen supra note *, at 555-61. I am in full 
When the ACLU enters the debate by challenging the University of Michigan's efforts to provide a safe harbor for its black, hispanic, and Asian students (a climate that a colleague of mine compared unfavorably with Mississippi in the 1960s), we should not be surprised that non-white students feel abandoned. When we respond to Stanford students' pleas for protection by accusing them of seeking to silence all who disagree with them, we paint the harassing bigot as a martyred defender of democracy. When we valorize bigotry we must assume some responsibility for the fact that bigots are encouraged by their newfound status as "defenders of the faith." We must find ways to engage actively in speech and action that resists and counters the racist ideas the first amendment protects. If we fail im this duty, the victims of hate speech rightly assume we are aligued with their oppressors.

We must also begin to think creatively as lawyers. We must embark upon the development of a first amendment jurisprudence that is grounded in the reality of our history and contemporary experience ${ }^{167}$

agreement with the need to work aggressively to disestablish institutional practices that marginalize non-whites and other subordinated groups, but I believe that the practices that exclude minorities from university professorships and the attitudes that devalue their contributions to the culture are inseparable from an atmosphere that engenders virulent racist speech. The speech/acts that "race" us must all be fought simultaneously for they are mutually dependent parts of a whole.

At Stanford, I have responded to some of my colleagues who have urged that we turn our attention from the relatively trivial concern of racist speech to more important concerns like affirmative action by suggesting that we tie the two efforts together. Why not hold the university responsible for individual violations of a regulation against racial harassment, much as the employer is held responsible under Title VII for the harassing acts of its employees? Each time a violation of the regulation against racist speech occurs there would be a public intervention in the form of a hearing and a public announcement of the judicial body's findings of fact. But instead of the university purishing the individuals involved, an affirmative remedy or reparation would be made by the university to the offended elass. The university might set aside a slot for a minority professor, or fund an additional full scholarship for a minority student, or cancel classes for a day and have a university-wide teach-in on racism. Such a proposal would directly address the institution's responsibility for maintaining a discrimination-free environment; it would have the symbolic value provided by a clear university position against certain forms of racist speech, and it would avoid first amendment problems by placing public sanctions on the institution rather than the individual speaker. If minority students knew that concrete institutional resourees were being spent to change the atmosphere of racism on campus they would be less concerned that individual racist speakers were escaping sanction. As things are, they hear the call for fighting racist attitudes and practices rather than speech as "just a lot of cheap talk."

167. Critical Race Theory seeks to develop a first amendment jurisprudence that reflects a personal understanding of the racist context. For examples of this scholarship, see D. BELL, AND WE ARE Not SAVED: THE ElUSIVE QUEST FOR RACIAL JUSTICE, supra note 157, at 224-33 (1987); Crenshaw, Race, Reform, and Retrenchment: Transformation and Legitimation in Anti-discrimination Law, 101 HARV. L. REv. 1331 (1988); see also Delgado, supra note 28, at 133 (arguing that an independent tort action for racial insults is both permissible and necessary); Hall, The Constitution and Race: A Critical Pérspéctive, 5 N.Y.L. ScH. J. HuM. RTs. 229 (1988) (providing a general overview of the dynamics of racism in the origin and development of constitutional law and attempting to refocus attention of constitutional celebrants to the "Black Freedom Struggle"); Matsuda, Affirmative Action and Legal Knowledge: Planting Seeds in Plowed-Up Ground, 11 HARv. WOMEN's 
(particularly the experiences of the victims of oppression). ${ }^{168}$ We must eschew abstractions of first amendment theory that proceed without attention to the dysfunction in the marketplace of ideas created by the racism and unequal access to that market. We must think hard about how best to launch legal attacks against the most indefensible forms of hate speech. Good lawyers can create exceptions and narrow interpretations limiting the harm of hate speech without opening the floodgates of censorship. We must weigh carefully and critically the competing constitutional values expressed in the first and fourteenth amendments.

A concrete step in this direction is the abandonment of overstated rhetorical and legal attacks on individuals who conscientiously seek to frame a public response to racism while preserving our first amendment liberties. I have ventured a second step in this Article by suggesting that the regulation of certain face-to-face racial vilification may be justified under current first amendinent doctrine as an analogy to the protection of certain classes of captive audiences on umiversity campuses. ${ }^{169}$ Most inportantly, we must continue this discussion. It must be a discussion in which the victims of racist speech are heard. We must be as attentive to the achievement of the constitutional ideal of equality as we are to the ideal of untrammeled expression. There can be no true free speech where there are still masters and slaves.

L.J. 12 (1988) (affirmative action should apply to the exploration of human knowledge- "we should bend our shared legal knowledge to accommodate new visions"); Matsuda, supra note 25; Minority Critiques of the Critical Legal Studies Movement, 22 HARv. C.R.-C.L. L. REV. 297 (1987) (collection of articles discussing the promise and the frustration that critical legal studies holds for minority scholarship and politics); Scales-Trent, Black Women and the Constitution: Finding Our Place, Asserting Our Rights, 24 HARV. C.R.-C.L. L. REV. 9 (1989) ("By creating two scparate categories for [society's] major social problems - 'the race problem' and 'the women's issue'-society has ignored the group that stands at the interstices of these two groups, black women in Ameriea."); Williams, Alchemical Notes: Reconstructing Ideals from Deconstructed Rights, 22 HARV. C.R.-C.L. L. REV. 401, 404-05 (1987) (detailing discomfort with that part of Critical Legal Studies which rejects rightsbased theory; asserting that CLS has ignored the degree to which rights-based theories have helped blacks, other minorities, and the poor).

168. See Matsuda, Looking to the Bottom: Critical Legal Studies and Reparations, 22 HARV. C.R.-C.L. L. REv. 323, 324-25 (1987) (suggesting that legal scholars adopt as law's "normative source" the perspective of those who have expericnced discrimination-a new epistemology based on "the actual experience, history, culture, and intellectual tradition of people of color in America").

169. See supra notes $99-103$ and accompanying text. Mari Matsuda has made a more radical venture, which I believe may well in the long run prove more satisfactory. She calls for a doctrinal change that would involve an explicit content-based rejection of narrowly defined category of racist speech, and she argnes that such an approach would be more protective of civil liberties than those which involve the balancing of competing interests or the likelihood of incitement to violence, approaches that can spill over to censor forms of political speech. See Matsuda, supra note 25, at 235661. 


\section{EPILOGUE}

"Enie, nrenie, minie, nro."

It is recess time at the South Main Street School. It is 1952, and I am nnie. Eddie Becker, Muck Makowski, John Thonıas, Terry Flynn, Howie Martin, and I are standing in a circle. Right feet thrust forward, the toes of our black, high-top Keds sneakers touching, forming a tight hub of white rubber at the center, our skinny blue-jeaned legs extend like spokes from the hub. Heads bowed, we are intently watching Muck, who is hunkered down on one knee so that he can touch our toes as he calls out the rhyme. We are enthralled and entranced by the drania of this boyhood ritual, this custoniary pre-game incantation. It is no less important than the game itself.

But niy mind is not on the ritual. I have lost track of the count that will determine whose foot nust be renioved fron the hub, who will no longer have a chance to be a captain in this game. I hardly feel Muck's index finger as it presses through the rubber to niy toes. My nind is on the rhyıne. I am the only black boy in this circle of towheaded prepubescent inales. Tinie stands still for nie. My palnis are sweaty and I feel a prickly heat at the back of my neck. I know that Muck will not say the word.

"Catch a tiger by the toe."

The heads stay down. No one looks at nie. But I know that none of them is picturing the capture of a large striped aninial. They are thinking of me, imagining my toe beneath the white rubber of my Keds sneaker-niy toe attached to a large, dark, thick lipped, burr-headed American fantasy/nightniare.

"If he hollers let hinı go."

Tigers don't holler. I wish I could right now.

My parents have told me to ignore this word that is ringing unuttered in my ears. "You must not allow those who speak it to nake you feel sniall or ugly," they say. They are proud, Mississippi-bred black professionals and long-tine political activists. Oft-wounded veterans of the war against the racist speech/conduct of Jin Crow and his niany relations, they have, on countless occasions, answered the bad speech/ conduct of racism with the good speech/conduct of their lives-representing the race, being sniarter, cleaner and inore inorally upright than white folk to prove that black folk are equal, are fully hunian-refuting the lies of the cultural niyth that is American racisni. "You niust know that it is their sniallness, their ugliness of which this word speaks," they say. 
I am struggling to heed their words, to follow their example, but I feel powerless before this word and its minions. In a moment's time it has made me an other. In an mstant it has rebuilt the wall between my friends' humamity and my own, the wall that I have so painstakingly disassembled.

I was good at games, not just a good athlete, but a strategist, a leader. I knew how to make my teammates feel good about themselves so that they played better. It just came naturally to me. I could choose up a team and make them feel like family. When other folks felt good, I felt good too. Being good at games was the mam tool I used to knock down the wall I'd found when I came to this white school im this white town. I looked forward to recess because that was when I could do the most damage to the wall. But now this rhyme, this word, had undone all my labors.

"Ene menie minie mo"

I have no memory of who got to be captain or what game we played. I just wished Muck had used "one potato, two potato ...." We always used that at home. 